NBER WORKING PAPER SERIES

\title{
COMMITMENT, RISK, AND CONSUMPTION: DO BIRDS OF A FEATHER HAVE BIGGER NESTS?
}

\author{
Stephen H. Shore \\ Todd Sinai \\ Working Paper 11588 \\ http://www.nber.org/papers/w11588
NATIONAL BUREAU OF ECONOMIC RESEARCH
1050 Massachusetts Avenue
Cambridge, MA 02138
August 2005

An earlier version of this paper circulated under the title, "Household Risk and the Demand for Housing Commitments." We thank Andrew Au, Misha Dworsky, Alex Janovsky, and Daniel Simundza for outstanding research assistance. We received helpful comments from Raphael Bostic, Christopher Carroll, Tom Davidoff, Joe Gyourko, Brigitte Madrian, Albert Saiz, Nick Souleles, Joel Waldfogel, Matt White, Justin Wolfers, and seminar participants at Columbia Business School, Harvard University, UC Berkeley, UC Davis, University of Illinois, University of Washington, and Wharton. Special thanks to Joel Waldfogel for suggesting the second half of the title. Shore gratefully acknowledges financial support from the National Institutes of Health - National Institute on Aging, Grant number P30 AG12836, and the Boettner Center for Pensions and Retirement Security at the University of Pennsylvania as well as the Zell/Lurie Real Estate Center at The Wharton School. Sinai received support from the Research Scholars Program at the Zell/Lurie Real Estate Center. The views expressed herein are those of the author(s) and do not necessarily reflect the views of the National Bureau of Economic Research.

(C)2005 by Stephen H. Shore and Todd Sinai. All rights reserved. Short sections of text, not to exceed two paragraphs, may be quoted without explicit permission provided that full credit, including (@ notice, is given to the source. 
Commitment, Risk, and Consumption: Do Birds of a Feather Have Bigger Nests?

Stephen H. Shore and Todd Sinai

NBER Working Paper No. 11588

August 2005

JEL No. E21, R21, D8

\title{
$\underline{\text { ABSTRACT }}$
}

We show that incorporating consumption commitments into a standard model of precautionary saving can complicate the usual relationship between risk and consumption. In particular, we present a model where the presence of plausible adjustment costs can cause a mean-preserving increase in unemployment risk to lead to increased consumption. The predictions of this model are consistent with empirical evidence from dual-earning couples. Couples who share an occupation face increased risk as their unemployment shocks are more highly correlated. Such couples spend more on owner-occupied housing than other couples, spend no more on rent, and are more likely to rent than own. This pattern is strongest when the household faces higher moving costs, or when unemployment insurance provides a less generous safety net.

\author{
Stephen H. Shore \\ The Wharton School \\ University of Pennsylvania \\ 3620 Locust Walk, 3012 SH-DH \\ Philadelphia, PA 19104 \\ sshore@wharton.upenn.edu \\ Todd Sinai \\ The Wharton School \\ University of Pennsylvania \\ 3620 Locust Walk, 3012 SH-DH \\ Philadelphia, PA 19104 \\ and NBER \\ sinai@wharton.upenn.edu
}




\section{Introduction}

Standard precautionary saving intuition, developed over the last 40 years, suggests that in the presence of increased income risk households should consume less and save more (Leland (1968), Sandmo (1970), Drèze and Modigliani (1972), Kimball (1990)). The models that generate this prediction assume that households can costlessly adjust their level and mix of consumption. However, this simplification is often at odds with reality. For example, to adjust housing consumption, homeowners must incur the costs of selling a house, buying a new one, and moving. These costs are large even when the change in housing consumption is small, as it would be if a household moved to a similar house across the street. Other goods, such as automobiles and cellular telephone plans, also have this commitment feature - namely that adjusting the type or quantity of consumption is costly. Warren and Tyagi (2003) argue that a typical American family earmarks 75 percent of their income for these "fixed expenses," items like a mortgage, car payments, child care, and health insurance.

This paper shows that incorporating commitments into a model of precautionary saving can complicate the usual relationship between risk and consumption. In the presence of commitment goods, a mean-preserving increase in income risk can lead to greater consumption and reduced saving, the opposite of what would be predicted by a model that does not include commitments. Prior research finds that exogenous consumption commitments impact people's attitude towards risk (Fratantoni (1998, 2001), Chetty (2004), Chetty and Szeidl (2004), Postlewaite et al. (2004)). We argue that the converse is also true: the risks people face affect their willingness to undertake consumption commitments. ${ }^{1}$

The intuition for our argument can be explained in the context of a dual-income household that consumes housing, which is costly to adjust, and food, which is not. The household faces

\footnotetext{
${ }^{1}$ Other work has considered the possibility of endogenous consumption commitments. Flavin (2001) endogenizes the size of a housing commitment in an adjustment cost model, and looks at the effect in a theoretical context on the intertemporal elasticity of substitution of nondurable goods and on asset prices. Postlewaite et al. (2004) refer to the endogeneity of consumption commitments to income risk, but does not model it. Chetty and Szeidl (2004) implicitly acknowledge the endogeneity of the size of consumption commitments in their empirical work by instrumenting for the price of the house.
} 
the risk that one or both spouses could become unemployed. If exactly one spouse becomes unemployed, the household must weigh the cost of moving against the benefit of choosing a level of housing consumption more appropriate to their new circumstances. In the face of this drop in permanent income, the household may decide to maintain their existing level of housing consumption and to reduce food consumption instead. In this case, the marginal utility of food would exceed that of housing. In hindsight, the household would have preferred a smaller initial housing commitment, not only to smooth total consumption over time but also to bring the marginal utility of current food and housing consumption closer together. By contrast, if both spouses become unemployed, they may find it worthwhile to pay the cost of moving in order to rebalance housing and food consumption. In that case, spending less on housing initially does not help to reallocate consumption across goods after unemployment, as moving already serves this function.

Understanding these possibilities, the household must choose an initial level of housing given the likelihood that one or both spouses will become unemployed. As the correlation between the couple's unemployment events increases, the probability that neither or both spouses will become unemployed goes up, while the probability that exactly one spouse will become unemployed falls. This is a mean-preserving increase in risk. In the one-unemployed state, the household is stuck in a house which is too big and lifetime utility would have been higher had it spent less on housing in the first place. Since the mean-preserving increase in risk reduces the probability of this state, it raises the optimal initial consumption of housing. The couple should also be more apt to choose renting over owning a home if it faces a high probability of dual unemployment. Since moving is particularly costly for homeowners, a household that is more likely to move should tend to rent in order to save on future transaction costs. Of course, these predictions apply only when moving costs are high enough to deter moving in all but the worst state.

We support these hypotheses with empirical evidence on the relationship between unemployment risk for dual-earning couples and their housing consumption. Although the 
intuition in our model applies to any consumption commitment, housing comprises a large fraction of household spending and requires a considerable commitment, and is therefore an obvious first place to look for evidence. Also, by restricting our attention to married couples who both work full-time, we can control for unobservable tastes for risk and differences in expected income. We proxy for the mean-preserving spread in a couple's income risk with whether spouses share the same occupation. Empirically, couples with both spouses in the same occupation have higher unemployment correlations than do couples in different occupations.

Using household-level data from the Integrated Public Use Microdata Series (IPUMS) of the U.S. Census, we find that same-occupation homeowners spend at least 2.1 percent more on their houses than do different-occupation couples, even after controlling for income, each spouse's occupation, and a host of other characteristics. By contrast, same-occupation renters, who face considerably lower moving costs than homeowners, spend no more on their rent than do different-occupation renters. In addition, same-occupation households are less likely to be homeowners than otherwise identical different-occupation households. Taken in concert, these three empirical facts are consistent with our model and inconsistent with alternative hypotheses, such as same-occupation couples having a larger precautionary savings motive or a stronger unobservable taste for housing.

As further evidence, we find that when moving costs are greater, the differences between same- and different-occupation couples in housing spending and probability of home ownership increase. Our proxy for high moving costs is whether the couple is unlikely to move anyway for exogenous demographic reasons. In addition, we do not observe this pattern for renters, for whom the costs of moving are already low.

Finally, we exploit variation across states in unemployment insurance programs. When unemployment insurance is more generous, households are less likely to move when both spouses become unemployed. Consistent with a theory of consumption commitments, we find that the difference in housing spending between same- and different-occupation home- 
owners is greater when the replacement rate of unemployment insurance is lower.

The remainder of this paper is arranged as follows: Section 2 sets up a simple model of consumption commitments which predicts that a mean-preserving increase in risk can increase a household's willingness to undertake consumption commitments; we describe the data and test this model in Section 3; and Section 4 concludes.

\section{A Model of Income Risk and Consumption Commitments}

In this section, we develop a simple model to show how consumption commitments can affect the relationship between income risk and consumption. We treat household labor income risk as exogenous and endogenize consumption. As in Chetty (2004), the model has two periods, $t=1,2$, and two goods, $h$ (housing) and $f$ (food). The units of $h$ and $f$ are normalized so that the price of each is 1 ; there is no goods price risk. For simplicity, we assume that household utility in a given period is the following separable function:

$$
u\left(h_{i}, f_{i}\right)=g\left(h_{i}\right)+\mu g\left(f_{i}\right)
$$

where $\mu$ is a parameter which indicates the relative importance of goods $h$ and $f$ to the household. $g$ is a differentiable, concave function. We will consider $g(x)=\ln (x)$ and

$g(x)=x-\frac{1}{2} \alpha x^{2}$ as two possible functional forms for $g$. For algebraic simplicity, we will set $\mu=1$ so that the two goods are equally important to the household, though loosening this assumption does not affect the substance of any of the results we obtain. Also, while separability is not strictly necessary, it is important that the marginal utility of food increases relative to the marginal utility of housing when food consumption falls. The family's lifetime expected utility is just a weighted average of the expected utility from the two periods:

$$
U=u\left(h_{1}, f_{1}\right)+\beta E\left[u\left(h_{2}, f_{2}\right)\right]
$$


For further algebraic simplicity, we set $\beta=1$, though again this assumption has no impact on the substance of our results. In the first period, the household receives an income $Y_{1}$ and decides how much of each good, $h_{1}$ and $f_{1}$, to consume. Remaining wealth, $Y_{1}-h_{1}-f_{1}$, is saved. Because we abstract from the investment problems examined in other work, we make the simplifying assumptions that there are no risky assets and that the riskless interest rate is zero. ${ }^{2}$ We also assume that the household cannot save in the housing asset. ${ }^{3}$ In our model, home ownership is like a two-period rental contract with a penalty for early exit. ${ }^{4}$ In the second period of the model, the household receives an income $\tilde{Y}_{2}$, which is not known at $t=1$. At that time, the household must allocate its wealth, $Y_{1}+\tilde{Y}_{2}-h_{1}-f_{1}$, between the two goods. If a household adjusts its consumption of good $h$, the transaction cost is $k\left(h_{1}\right)$. It is this transaction cost, which is generally thought to be higher for homeowners than for renters, which gives $h$ its commitment feature. ${ }^{5} \quad$ While the case of proportional transaction costs, $k=c h_{1}$, is probably the most empirically relevant, fixed transaction costs provide greater analytic tractability. Both types of transaction costs generate the results

\footnotetext{
${ }^{2}$ If there is housing cost risk, home owning may hedge future housing costs as in Sinai and Souleles (2005). A correlation between housing costs and income risk, as in Davidoff (2005) and Campbell and Cocco (2003), may provide a further boost to housing demand.

${ }^{3}$ Transforming the price of a housing asset into the flow cost of the consumption of housing services, the homeowner's equivalent of rent, is a well-documented procedure that underlies our $h$ notation. For an exposition of the user cost of owner-occupied housing, see Hendershott and Slemrod (1983) or Poterba (1984). The consensus of the literature (Henderson and Ioannides (1983), Goetzmann (1993), Brueckner (1997), and Flavin and Yamashita (2002)) is that people are forced to over-invest in housing to satisfy their consumption needs, hence the demand for housing for consumption is binding, while the desire for housing as investment is not. Consequently, the dual nature of housing as an asset and consumption good does not preclude its use as an indicator of consumption. Although showing the conditions under which households might save precautionarily in housing is beyond the scope of this model, we will come back to this issue later to make sure a savings motive is not driving our empirical results.

${ }^{4}$ Equivalently, home owning can be a purchase and resale of a housing asset that neither appreciates nor depreciates.

${ }^{5}$ While it is difficult to ascertain the total utility cost of moving, the cost for owners is typically assumed to be large. In addition to a realtor's fee of 6 percent, a moving homeowner must pay transfer taxes, financing costs for a new home, movers, and must incur a host of nonpecuniary costs. These costs include the search for a new home, the time cost of selling the original home, and the psychic costs of uprooting. Renters face much lower moving costs. They have smaller or no realtor's fees, taxes, or upfront financing costs and do not have to sell their prior apartment. Also, search costs for rental housing are lower, since the market is thicker and more commoditized.
} 
discussed. Therefore, a household's inter-temporal budget constraint can be written as:

$$
\begin{aligned}
& Y_{1}+\tilde{Y}_{2}=2 h_{1}+f_{1}+f_{2} \text { if } h_{1}=h_{2} \\
& Y_{1}+\tilde{Y}_{2}=h_{1}+k\left(h_{1}\right)+h_{2}+f_{1}+f_{2} \text { if } h_{1} \neq h_{2} .
\end{aligned}
$$

To determine the optimal consumption in the first period, we determine optimal consumption and indirect utility in the second period and then work backwards. In the second period, the household maximizes

$$
u\left(h_{2}, f_{2}\right)=g\left(h_{2}\right)+g\left(f_{2}\right)
$$

subject to constraint (3). Therefore, optimal consumption is

$$
\begin{array}{r}
\left\{h_{2}=f_{2}=\frac{1}{2}\left(Y_{1}+\tilde{Y}_{2}-h_{1}-f_{1}-k\left(h_{1}\right)\right)\right\} \text { if } h_{2} \neq h_{1} \\
\quad \text { and }\left\{h_{2}=h_{1} ; f_{2}=Y_{1}+\tilde{Y}_{2}-2 h_{1}-f_{1}\right\} \text { if } h_{2}=h_{1}
\end{array}
$$

and indirect utility is

$$
\begin{aligned}
& v\left(Y_{1}+\tilde{Y}_{2}-h_{1}-f_{1}, h_{1}\right)=g\left(h_{1}\right)+g\left(Y_{1}+\tilde{Y}_{2}-2 h_{1}-f_{1}\right) \text { if } h_{2}=h_{1} \\
& v\left(Y_{1}+\tilde{Y}_{2}-h_{1}-f_{1}, h_{1}\right)=2 \bullet g\left(\frac{1}{2}\left(Y_{1}+\tilde{Y}_{2}-h_{1}-f_{1}-k\left(h_{1}\right)\right)\right) \text { if } h_{2} \neq h_{1}
\end{aligned}
$$

where $h_{2}=h_{1}$ if and only if

$$
2 \bullet g\left(\frac{1}{2}\left(Y_{1}+\tilde{Y}_{2}-h_{1}-f_{1}-k\left(h_{1}\right)\right)\right) \leq g\left(h_{1}\right)+g\left(Y_{1}+\tilde{Y}_{2}-2 h_{1}-f_{1}\right)
$$

The household will not adjust housing consumption, $h$, unless the shock to wealth is large enough that the benefits of rebalancing consumption exceed the costs of moving. In the presence of small shocks, when the desired level of housing consumption is not very different 
from the commitment level, the household will prefer to maintain the commitment level of housing consumption. ${ }^{6}$ The benefits of adjusting housing consumption are swamped by the costs of moving. If it experiences a large shock, the household is willing to pay a cost to adjust housing consumption. ${ }^{7}$ As described by Chetty (2004), this leads to a non-convex indirect utility function, shown in Figure 2.1. At the kink point in the figure, the household is indifferent between moving and not moving. The figure shows that the marginal utility of wealth is much higher when the household is just rich enough that it does not have to reduce housing consumption (to the right of the kink) than when it is just poor enough that it does have to (to the left).

Once we have solved for the optimal consumption rule in the second period, we can solve for optimal consumption in the first period. The household's lifetime utility function (2) can be rewritten as:

$$
U\left(h_{1}, f_{1}\right)=g\left(h_{1}\right)+g\left(f_{1}\right)+E\left[\max \left\{\begin{array}{c}
g\left(h_{1}\right)+g\left(Y_{1}+\tilde{Y}_{2}-2 h_{1}-f_{1}\right), \\
2 \bullet g\left(\frac{1}{2}\left(Y_{1}+\tilde{Y}_{2}-h_{1}-f_{1}-k\left(h_{1}\right)\right)\right)
\end{array}\right\}\right] .
$$

To better understand the optimal consumption rule in the first period, we must add structure by making assumptions about the distribution of $\tilde{Y}_{2}$. In this paper, we explore an empirically relevant type of income risk - unemployment risk. ${ }^{8}$ We assume that the household has two wage earners, a husband and wife, and that uncertainty comes from the possibility that one

\footnotetext{
${ }^{6}$ Another way households could respond is by reducing the maintenance expenditures on their houses. In that case, it would be more difficult for us to find an effect empirically since housing consumption would be adjustable within a small range. Gyourko and Tracy (2003) show that households defer maintenance to smooth consumption over transitory shocks to income. Davidoff (2004) presents evidence that older households spend less on housing maintenance and experience lower house price appreciation.

${ }^{7}$ This result contrasts with Browning and Crossley (2004) who show that households respond to small shocks by reducing expenditure on new durables such as pillows and socks but respond to larger shocks by reducing consumption of non-durables as well. The difference in these results stems from Browning and Crossley's focus on the impact of liquidity constraints and transitory or small shocks on consumption.

${ }^{8}$ The negative skewness of unemployment risks will be important in generating our results, since households that move will move only into smaller houses. While the intuition would still apply, the direction of the model's predictions will be quite different for other types of risks. For example, if households face increasing lottery risk (increasing the probability of winning a lottery large enough to induce moving while decreasing the probability of winning a lottery too small to induce a move), it should lead to even greater reductions in housing consumption than would be predicted by a model of precautionary saving without consumption commitments.
} 
or both may become unemployed in the second period. To reduce the number of states to consider, we make the simplifying assumption that income for either husband or wife is $Y_{2}^{E}$ if employed and $Y_{2}^{U}$ if unemployed. The husband's probability of unemployment is $p$ while the wife's is $q$. There is a correlation $\rho$ between the employment status of the husband and wife. Therefore, the distribution of household income in the second period, $\tilde{Y}_{2}$, can be written as:

$$
\begin{aligned}
& \tilde{Y}_{2}=2 Y_{2}^{E} \text { with probability } 1-p-q+\phi \\
& \tilde{Y}_{2}=Y_{2}^{E}+Y_{2}^{U} \text { with probability } p+q-2 \phi \\
& \tilde{Y}_{2}=2 Y_{2}^{U} \text { with probability } \phi, \text { where } \\
& \phi \equiv p q+\rho \sqrt{p q(1-p)(1-q)} .
\end{aligned}
$$

The three states correspond to both spouses being employed, exactly one being unemployed, and both being unemployed. Increasing the correlation of the couple's unemployment events, $\rho$, while holding $p$ and $q$ fixed is equivalent to adding a mean-preserving spread in the distribution of household labor income, increasing the probability of the best and worst outcomes (neither or both unemployed) while decreasing the probability of the medium outcome (exactly one unemployed). However, the expected household income,

$$
E\left[\tilde{Y}_{2}\right]=2 Y_{2}^{E}-(p+q)\left(Y_{2}^{E}-Y_{2}^{U}\right),
$$

is independent of $\rho$ and depends on the rates of unemployment, $p$ and $q$, additively. ${ }^{9}$

\subsection{Risk and Consumption With and Without Commitment}

A standard model of precautionary saving is a special case of the model described above in which $k=0$. If there are no costs to moving, then the household is always weakly better

\footnotetext{
${ }^{9}$ Other parameters besides $\rho$ could be modified to induce a mean-preserving increase in risk. For example, a mean-preserving spread could be created by decreasing $Y_{2}^{U}$ while increasing $Y_{2}^{E}$. We focus on variation in $\rho$ both because of its novel implications and also because it can be identified in the data relatively cleanly.
} 
off by changing the level of housing consumption. In this case, the expected utility function is just

$$
U\left(h_{1}, f_{1}\right)=g\left(h_{1}\right)+g\left(f_{1}\right)+E\left[2 \bullet g\left(\frac{1}{2}\left(Y_{1}+\tilde{Y}_{2}-h_{1}-f_{1}\right)\right)\right] .
$$

Taking first order conditions for $h_{1}$ and $f_{1}$ and equating them reveals that at an optimum, $h_{1}=f_{1}$. Therefore, the utility function can be rewritten as:

$$
U\left(h_{1}\right)=g\left(h_{1}\right)+E\left[g\left(\frac{1}{2}\left(Y_{1}+\tilde{Y}_{2}-2 h_{1}\right)\right)\right] .
$$

Then, the first order condition can be rewritten as:

$$
0=\left[\begin{array}{c}
g^{\prime}\left(h_{1}\right)+(1-p-q+\phi)\left[-g^{\prime}\left(\frac{1}{2}\left(Y_{1}+2 Y_{2}^{E}-2 h_{1}\right)\right)\right] \\
+(p+q-2 \phi)\left[-g^{\prime}\left(\frac{1}{2}\left(Y_{1}+Y_{2}^{E}+Y_{2}^{U}-2 h_{1}\right)\right)\right] \\
+\phi\left[-g^{\prime}\left(\frac{1}{2}\left(Y_{1}+2 Y_{2}^{U}-2 h_{1}\right)\right)\right]
\end{array}\right] .
$$

Lemma 1 Let $h_{1}^{*}$ be the solution to (13). If $g^{\prime \prime \prime}>0$, then $\frac{d h_{1}^{*}}{d \rho}<0$; if $g^{\prime \prime \prime}=0$, then $\frac{d h_{1}^{*}}{d \rho}=0$; if $g^{\prime \prime \prime}<0$, then $\frac{d h_{1}^{*}}{d \rho}>0$.

Proof. See Appendix A.1.

The result is a simple illustration of precautionary saving and follows Kimball (1990). $\rho$ is a measure of household risk which is independent of expected household wealth. For utility functions with positive third derivatives (such as power, log, and exponential), as the amount of household risk increases, optimal consumption, $h_{1}$ (which is also equal to $f_{1}$ ), falls and saving, $Y_{1}-h_{1}-f_{1}$, increases. Most economists take the $g^{\prime \prime \prime}>0$ to be a realistic description of people's preferences, and therefore predict a negative relationship between risk and consumption. For quadratic utility functions $\left(g^{\prime \prime \prime}=0\right)$, increasing risk has no impact on consumption or saving.

This precautionary saving result can be reversed if there is a cost of adjusting housing consumption, so $k>0$ and is in a range where it is optimal to move only when both spouses 
become unemployed. Even when $g^{\prime \prime \prime} \geq 0$, increasing risk may actually increase consumption. Since this is difficult to show analytically for most utility functions and costs of adjustment, we prove this result for the simple case of quadratic utility and fixed adjustment costs. The subsequent sections will relax these assumptions and show that the same results can be obtained numerically under more realistic assumptions about utility and adjustment costs.

In the quadratic utility case with fixed adjustment costs, the household's objective function is:

$$
\left.\begin{array}{rl}
U\left(h_{1}, f_{1}\right)= & \left(h_{1}-\frac{1}{2} \alpha h_{1}^{2}\right)+\left(f_{1}-\frac{1}{2} \alpha f_{1}^{2}\right) \\
& +E\left[\max \left\{\begin{array}{c}
{\left[\begin{array}{c}
{\left[h_{1}-\frac{1}{2} \alpha h_{1}^{2}\right.} \\
+\left(Y_{1}+\tilde{Y}_{2}-2 h_{1}-f_{1}\right)-\frac{1}{2} \alpha\left(Y_{1}+\tilde{Y}_{2}-2 h_{1}-f_{1}\right)^{2}
\end{array}\right],} \\
{\left[\left(Y_{1}+\tilde{Y}_{2}-h_{1}-k-f_{1}\right)-\frac{\alpha}{4}\left(Y_{1}+\tilde{Y}_{2}-h_{1}-k-f_{1}\right)^{2}\right.}
\end{array}\right]\right.
\end{array}\right] .
$$

Lemma 2 Let $\left\{h_{1}^{*}, f_{1}^{*}\right\}$ maximize (14). If model parameters make it strictly optimal to set $h_{2}^{*} \neq h_{1}^{*}$ if and only if $\tilde{Y}_{2}=2 Y_{2}^{U}$, then $\frac{d h_{1}^{*}}{d \rho}>0$.

Proof. See Appendix A.2.

When it is optimal to adjust housing consumption only when both spouses become unemployed, increasing risk $(\rho)$ affects consumption through three distinct channels. First, standard precautionary saving implies that increased risk leads to reduced consumption when the third derivative of utility is positive. Since we assumed quadratic utility for Lemma 2, this channel is absent in this case. Second, increasing risk effectively reduces wealth. As $\rho$ goes up, the probability of both spouses becoming unemployed increases. This increases the probability of adjusting housing consumption and therefore increases expected moving costs. This makes the household poorer and reduces consumption. Third, increasing risk reduces the probability that exactly one spouse will become unemployed. In the one-unemployed state, the household chooses to reduce food consumption and to maintain housing consumption. Therefore, the marginal utility of food consumption exceeds the marginal utility of 
housing consumption. Reducing housing consumption in the first period lowers housing consumption and increases food consumption in the second period. This rebalancing of consumption increases utility in the one-unemployed state, when moving costs deter the household from moving to a smaller house to increase food consumption. Therefore, an increase in risk that reduces the likelihood of this state increases optimal first-period housing consumption. Lemma 2 shows that the third channel dominates the first two, so that increased risk leads to increased initial housing consumption.

\subsection{Graphical Illustration of Household Risk and Commitment}

The proof in the last subsection assumed that preferences were quadratic and adjustment costs were fixed. While these assumptions are necessary to obtain an analytically tractable solution, they are not necessary to obtain the same qualitative results. To develop intuition behind these results and to show that they are not confined to a special case, we begin by showing the effect graphically. We use the two-period model described in Section 2 in which uncertainty comes from the possibility that one or both spouses could become unemployed. ${ }^{10}$ Utility is assumed to be of the $\log$ form, $g(\cdot)=\ln (\cdot)$, and we consider proportional moving costs, $k=c h_{1}$. We vary household risk by changing $\rho$, the correlation of spouses' unemployment.

In a standard model without moving costs, $k=0$, precautionary saving is obtained because the marginal utility of wealth goes up more than twice as much when both husband and wife become unemployed than when only one becomes unemployed. Therefore, a meanpreserving increase in risk increases the expected marginal utility of wealth. As a result, increasing risk reduces the optimal level of consumption whenever the cost of adjusting consumption is small.

This is illustrated by Figure 2.2, which shows the marginal lifetime utility of first-period housing consumption, $d U\left(h_{1}, f_{1}^{*}\left(h_{1}\right)\right) / d h_{1}$, for different levels of housing consumption in

\footnotetext{
${ }^{10}$ We assume that $Y_{2}^{U}=0.5 \cdot Y_{2}^{E}$. Furthermore, we assume $Y_{1}=2 \cdot Y_{2}^{E}$, so that household income stays constant if both partners remain employed. Without loss of generality, we normalize by setting $Y_{2}^{E}=1$.
} 
different states of the world. In other words, holding wealth fixed, how does a marginal increase in first-period housing consumption impact lifetime utility if both spouses (or one or none) are employed in the second period? These lines represent the first-order condition for first-period housing in various states if the second-period realization were known. The optimal level of housing if the second-period realization were known is simply the point where a given line crosses the y-axis. ${ }^{11}$ If both husband and wife are unemployed, the " $\triangle$ " plot, then the marginal utility of first-period housing consumption is strongly negative; the family could have increased lifetime utility had it bought a smaller house initially. By contrast, if both spouses are employed, the " $\square$ " plot, then the marginal utility of first-period housing is positive; the family could have increased lifetime utility had it bought a bigger house initially. The " $O$ " plot, representing the marginal utility when exactly one spouse becomes unemployed, is in between.

Plot "+" in this figure is merely an average of the " $\triangle$ ", " $о$ ", and " $\square$ " plots, weighted by the respective probabilities of these three outcomes. Since the first-order condition for $h_{1}$ is

$$
E\left[d U\left(h_{1}, f_{1}^{*}\left(h_{1}\right)\right) / d h_{1}\right]=0
$$

the optimal level of consumption is simply the point where the expected marginal utility plot, "+", crosses the y-axis. A mean-preserving spread increases the weight on the neither employed and both employed states (" $\triangle$ " and " $\square$ " plots) by reducing the weight on the one employed state ("o" plot). Since the " $\triangle$ " plot (neither employed) is substantially lower than the " $O$ " plot (one employed) and the " $\square$ " plot (both employed), a mean preserving spread will move the expected marginal utility (the "+" plot) down and therefore reduce the optimal level of initial housing consumption. This is a graphical representation of precautionary saving.

Figure 2.3 depicts the same problem as Figure 2.2, but with a 10 percent proportional

\footnotetext{
${ }^{11}$ These plots assume that the level of food consumption in the first period is chosen optimally given first-period housing but that the second-period employment realization is not known in the first period. We use the following parameters: $Y_{1}=2, Y_{2}^{E}=1, Y_{2}^{U}=.5, p=q=.1, \rho=0.2$.
} 
cost of adjusting housing consumption, $c=0.1$. Throughout the range of interest, it is optimal to adjust housing consumption only if both spouses become unemployed. The noteworthy feature of this figure is the extremely low marginal utility of first-period housing consumption when exactly one spouse becomes unemployed. The marginal utility of firstperiod housing is highly negative for households with exactly one unemployed spouse because these households have to reduce food consumption dramatically in order to maintain their housing consumption.

When exactly one spouse becomes unemployed, reducing first-period housing consumption by $\$ 1$ increases lifetime utility because it allows the household to increase second-period food consumption - which has a relatively high marginal utility - by $\$ 2$ (and decrease secondperiod housing consumption - which has a relatively low marginal utility - by $\$ 1$ ). In this context, inducing a mean-preserving spread has a very different effect than if moving costs were absent. An increase in risk reduces the probability of the state in which exactly one spouse is unemployed, when the marginal utility of first-period housing is highly negative. Since the "one employed" line is substantially below the midpoint of the "both employed" and "neither employed" lines, the mean-preserving spread actually increases expected marginal utility and therefore increases the optimal level of initial housing consumption.

These graphs represent the fundamental idea of this paper, that moving costs complicate the relationship between risk and consumption. Unlike a traditional model of precautionary saving, increasing risk can actually increase the optimal level of consumption in a setting with consumption commitments. This result is generated because increasing risk reduces the probability of exactly one person becoming unemployed. Since this is the state in which the household is stuck with a house that is much too big and wish they had bought a smaller house initially, optimal housing consumption increases. 


\subsection{Calibrating the Impact of Household Risk on Consumption Commitments}

Section 2.2 developed the intuition for the result that increasing risk may increase consumption. This section performs a calibration to examine the potential size of this effect. The calibration assumes log utility and proportional moving costs, and presents the numerical solutions to (8) given income shocks (9) for various parameter values.

Given sensible parameters, this setup implies a substantial positive relationship between income correlation and housing consumption. For example, if the income for the unemployed is half that of the employed, there is no earnings growth for the employed, the probability of becoming unemployed is 10 percent, and the cost of moving is 10 percent, ${ }^{12}$ it is optimal to adjust housing only if both spouses become unemployed. Figure 2.4 plots consumption for various levels of income correlation in this case. Increasing the correlation of unemployment from no correlation to perfect correlation increases optimal spending on housing by 2.9 percent (and decreases optimal non-housing consumption by 1.0 percent). The saving rate falls from 3.8 percent to 2.9 percent when the correlation of income increases.

These results for housing consumption and saving are exactly the reverse of what would be predicted by a precautionary saving model without moving costs. With an otherwise identical setup without moving costs, the same increase in income correlation leads to a 1.2 percent reduction in both housing and non-housing consumption and an increase in the saving rate from 3.3 percent to 4.4 percent. Since this is a two-period model with stylized assumptions about time discounting, rates of return on saving, risk aversion, the relative importance of housing and food consumption, and the income shares of couples, these numbers should be taken with a grain of salt. Given different parameters or more realistic assumptions about risk aversion and time, the effect could vary. However, this calibration provides the intuition that in the presence of moving costs, increasing risk can lead to a substantial increase in housing consumption and a substantial reduction in saving.

\footnotetext{
${ }^{12} Y_{1}=2, Y_{2}^{E}=1, Y_{2}^{U}=0.5, p=q=0.1, k=0.1$.
} 
This effect is similar in size to - but of the opposite sign from - what would be predicted by a standard model of precautionary saving.

Table A.1 presents a summary of the results for a variety of parameters. For the reasons discussed in Section 2.2, increasing the correlation of unemployment, $\rho$, increases optimal housing consumption whenever it is optimal to move only when both spouses are unemployed. Unsurprisingly, there are many sets of parameter values for which it is not optimal to move only in this state. Reducing the cost of moving makes moving optimal in states where only one or even neither spouse is unemployed. Similarly, adjusting the income earned by the unemployed also impacts when it is optimal to move. When the income of the unemployed is low enough, it is optimal to move even when only one spouse is unemployed; when the income of the unemployed is high enough, it is not optimal to move even when both spouses are unemployed. For parameters that make it optimal to move when one or both spouses are unemployed, the impact of household risk on housing consumption varies but is weaker than when it is optimal to move only in the worst state. $^{13}$

\subsection{Risk and the Willingness to Undertake Commitments}

The previous subsections have shown that in the presence of substantial moving costs, increasing risk could lead homeowners to spend more on housing. But increasing risk increases the probability that both spouses will be unemployed, and therefore the probability of needing to move and to pay a moving fee. While households need to consume housing, they need not take on such large expected moving costs. Renting a home has a variety of disadvantages (e.g. moral hazard costs, rent is not tax-deductible), but it has substantially lower adjustment costs. If households have exogenous heterogeneity in their preference for home ownership, then on average they should be more likely to rent as risk increases, since the odds of moving, and therefore the effective cost of owning a home, goes up.

\footnotetext{
${ }^{13}$ On one hand, a mean-preserving increase in risk creates a precautionary saving motive to reduce total consumption. On the other hand, this increase in risk lowers the probability of moving and therefore expected moving costs, reducing the effective price of housing, and leading to increased housing consumption. Which of these effects dominates depends on the parameters chosen.
} 
To demonstrate this, we make the stylized assumption that renting a home involves almost no moving costs, so that the household can always adjust housing consumption. By contrast, owning a home involves a substantial moving cost (10 percent of housing consumption), so that given the other parameter assumptions it will be optimal to move only when both spouses are unemployed. In this setting, we compute the income premium that a household must be offered to make it willing to accept the higher moving costs of home ownership. Figure 2.5 plots household utility with and without moving costs for various levels of spousal income correlation, $\rho$. While consumption falls as risk increases when there are substantial moving costs, utility falls as risk increases regardless of moving cost. However, utility falls faster when moving costs are higher.

This figure also plots the premium that households demand to make them willing to choose the high transaction cost option, owning (the " $\triangle$ " plot). This premium is increasing in household risk, $\rho$. For example, when a couple's income risks are uncorrelated, the household must be offered 1.4 percent higher lifetime income to make it willing to buy a home instead of rent. However, when a couple's income risks are perfectly correlated, they must be offered 2.1 percent higher income to make them willing to buy a home.

\section{Empirical Evidence}

In this section, we look for evidence consistent with the theory developed in Section 2. First, we must identify an increase in household unemployment risk in the data. Our proxy for unemployment correlation, $\rho$, is whether the couple shares the same occupation. We document that same-occupation couples are substantially more likely to be either both employed or both unemployed, and less likely to have just one spouse unemployed. In this sense, these couples face higher unemployment correlations than couples who do not share an occupation. Next, we show that for homeowners, adjustment costs are high enough to deter moving in all but the worst states of the world. Home-owning couples who both become unemployed are much more likely to move than couples in which one or both spouses remain 
employed.

In this setting, we examine the testable predictions of our model. First, do couples with higher income correlations (e.g. same-occupation couples) spend more on consumption commitments (e.g. housing)? Second, is this relationship limited to those with relatively high adjustment costs (e.g. homeowners and not renters, or those who were unlikely to move for other reasons)? Third, do couples with higher income correlations choose housing consumption with lower adjustment costs (e.g. renting)? Fourth, is the relationship between income correlation and housing consumption strongest when dual unemployment is most likely to induce moving (e.g. when unemployment insurance is less generous)?

Our theory can be differentiated from reasonable alternatives by these predictions. For example, if same-occupation couples had a high unobservable taste for housing or home ownership, then relative to different-occupation couples they should be more likely to own their homes and should spend more on rent. We would also not expect to see any difference between same- and different-occupation couples in the link between moving costs and housing consumption. Alternatively, if same-occupation couples responded to their additional risk by saving more and investing this wealth in owner-occupied housing, they should be more likely to own their homes. Also, there would be no reason to believe that same-occupation couples should spend relatively less on housing when they are more likely to move soon. All of these predictions differ from those of our model.

\subsection{Data and Variable Construction}

To estimate these empirical relationships, we need a source of household-level data that contains information about housing consumption, moving, changes in employment status, income, and the occupations of both husbands and wives. No one data set contains information about all of these variables for a large number of households. For data on changes in employment status, occupation, and the probability of moving, we use the April 1996 panel of the Survey of Income and Program Participation (SIPP), which follows a panel of 
households for 48 months between April 1996 and March 2000. When we examine the effect of sharing an occupation on housing consumption and home ownership, we use a pooled cross-section of households from the 1980, 1990, and 2000 Integrated Public Use Microdata Series (IPUMS) of the U.S. Census. These data are a 1 percent random sample of responses to the U.S. Decennial Census and contain self-reported house values, incomes, and occupations, as well as employment status, a limited moving history, and a number of demographic variables and geographic identifiers. ${ }^{14}$

The SIPP initially contains $3,897,211$ person $\times$ month observations, and the three waves of the IPUMS together initially contain 2,778,194 household-level observations. ${ }^{15}$ We impose several restrictions on our samples which, taken together, reduce the number of usable observations to 270,136 household $\times$ month observations for the SIPP and 302,342 household observations for the IPUMS. (These restrictions are detailed in Appendix Table A.2.) In both the SIPP and IPUMS, we limit our attention to married couples in which both spouses are currently employed. In the IPUMS, we also impose the restrictions that both spouses work full-time and live in Metropolitan Statistical Areas (MSAs). We consider only married households so we can distinguish empirically between occupational choice and unobserved taste for risk. In the IPUMS, we discard households containing part-time or unemployed spouses because it is difficult to accurately measure their occupation, as well as their potential earnings capacity. ${ }^{16}$ We restrict our attention to MSAs so we can control for local housing costs. MSAs are geographical areas defined by the Bureau of the Census intended to correspond to labor market areas and thus match up well to local housing markets.

\footnotetext{
${ }^{14}$ Owners typically overestimate the value of their houses by 6 percent on average, but their errors do not appear to be systematically related to any observable variables (Goodman and Ittner (1992)). Since house value and income are recorded as ranges, we assign the midpoint of the range or 1.5 times the top code. All dollar values are converted to real (2000) using the CPI.

${ }^{15}$ We pool the three decades together for greater statistical power, especially for when we examine various subsamples of the data. We will also report results from some of the key regressions when estimated on each decade separately.

${ }^{16}$ In particular, one spouse might keep their labor supply in reserve as a buffer in case the other spouse becomes unemployed (Cullen and Gruber (2000)). Since the relevant metric for a partially-employed couple is potential income and since it is hard to measure potential income for part-time workers, we restrict our attention to those families who appear to be working at their potential.
} 
We make extensive use of occupation data in both data sets. The IPUMS reports one occupation variable with 227 categories that is consistently defined over all three waves, based on occupation definitions from 1950. As detailed in Table 3.1.A, the average rate of same-occupation couples across all occupations in the sample is 9.6 percent. In the SIPP data summarized in Table 3.1.B, the prevalence of same-occupation couples is somewhat lower, at 3.2 percent, since occupation definitions in the SIPP are more granular, with 463 three-digit codes. Table 3.2 lists the 20 occupations in the IPUMS with the highest fraction of same-occupation couples. The fraction of same-occupation couples varies widely by occupation - it ranges from 15 percent for physicians to zero for many occupations not listed in the table. That range cannot be fully explained by random matching. Column 3 reports the fraction of same-occupation couples that would arise if couples were paired at random. While random matching might account for some of the same-occupation couples in a few common occupations (managers, sales workers, clerical workers), it does not explain the high rate of same-occupation couples among doctors or lawyers. Nor does the frequency of same-occupation pairings appear to be income-related.

Consistent with the framework developed in Section 2, our proxy for income risk will be unemployment; the risk of exactly one spouse becoming unemployed is considered a "small" risk and the risk of both spouses becoming unemployed is considered a "big" risk. In the SIPP, we define a person as employed when they have a job all month or have a job part of the month but spend no time as laid off or searching for a job; we define them as unemployed when they spend all month unemployed or have a job only part of the month and spend some of the month as laid off or searching for a job. In the IPUMS, we define a person as unemployed when their stated usual hours of work in that year are zero. While we will restrict our sample to dual-employed couples, we will want to control for the probability of unemployment. We impute that probability for a husband (wife) as the average rate of unemployment for husbands (wives) in the same occupation and year, excluding the husband's (wife's) own observation. We compute this measure separately for husbands 
and wives, imposing the sample restrictions described in Table A.2 (except for the full-time worker restriction). ${ }^{17}$ Table 3.1 shows that the annual unemployment rate for home-owning husbands $(p)$ in the IPUMS averages 6.5 percent and the unemployment rate for wives $(q)$ averages 13.5 percent. The higher unemployment rates in the SIPP, 8.6 and 25.1 percent, respectively, are consistent with the more stringent definition of employment in these data.

For some of our empirical work, we will need an exogenous proxy for the likelihood of moving. We impute the likelihood of moving as the rate of recent moving by similar families. The IPUMS reports whether the family moved into their house within the last year. We construct the average rate of having moved in the previous year by husband's age $\times$ husband's education $\times$ presence of children cells. We define the bins using 10-year age brackets, nine education categories, and an indicator for whether the family has any children, and take the average for all of the households in that bin excluding the household in question. In the SIPP, where we need to know if the household actually moved after an unemployment event, we identify households that move by whether they change addresses between two consecutive monthly interviews.

\subsection{Sharing an Occupation, Unemployment Correlation, and the Probability of Moving}

For our empirical setup to be an appropriate test of the theory in Section 2, sharing an occupation must represent an increase in risk: same-occupation couples must have higher unemployment correlations. Also, households must be much more likely to move when both spouses become unemployed. We use the SIPP data to examine whether these two conditions apply.

In our data, same-occupation couples indeed have a higher unemployment correlation than different-occupation couples. This fact is documented in Table 3.3, which reports the

\footnotetext{
${ }^{17}$ Since people who are unemployed may state that they have no occupation - even when they have worked and plan to work in a given occupation - this procedure likely underestimates the true unemployment rate by occupation.
} 
probability of one or both spouses becoming unemployed at some point over the next six months, conditional on both being employed in the current month, broken out for sameand different-occupation couples. While the overall rate of becoming unemployed is roughly similar for same- and different-occupation couples (4.0 percent vs. 4.4 percent for husbands, and 7.1 vs. 8.0 percent for wives), same-occupation couples have higher rates of both becoming unemployed (1.5 percent vs. 0.7 percent) and both remaining employed (90.4 percent vs. 88.3 percent), and lower rates of just one spouse becoming unemployed (8.2 percent vs. 11.1 percent). These rates of single- and dual-unemployment imply a correlation of unemployment events of 5.7 percent for different-occupation couples but of roughly 23.7 percent for same-occupation couples. ${ }^{18}$

We also find that dual-unemployment substantially increases the likelihood of moving. Table 3.4 reports the fraction of home-owning households that move within six months of one or both spouses becoming unemployed. Conditioning on both spouses being employed in the previous month, we measure the change in employment status as the number of spouses (zero, one, or two) who are unemployed in the current month. Over the subsequent six months, the rate of moving is just over 2 percent if both spouses had remained employed. If just one of the spouses had become unemployed, the probability of moving during the subsequent 6 months increases by nearly 2 percentage points, to almost 4 percent. But if both spouses had become unemployed, the likelihood of a move skyrockets by almost 6 percentage points more, to nearly 10 percent. In results not presented in the tables, we have found a similar acceleration in moving rates at one-month and 12-month horizons. ${ }^{19}$ We

\footnotetext{
${ }^{18}$ We use unemployment here, even though some of the unemployment spells are probably voluntary, because the concept appears to be relatively well-measured in the SIPP. If we instead use the SIPP's layoff variable, the correlations are nearly the same. For same-occupation households, the correlation of being laid off over the next six months conditional on being employed this month is 25.1 percent, while for different-occupation households it is about 1.4 percent. Splitting the sample by "same industry" rather than "same occupation" yields essentially the same results.

${ }^{19}$ The results in Table 3.4 suggest there is a relationship between joint unemployment and moving. However, since the dual-unemployment observations in this table do not map one-for-one to the dualunemployment state described in the model, this table does not identify a model parameter. The definition of joint unemployment in Table 3.4 is that both spouses transition from employment to unemployment in the same month. This misidentifies couples with somewhat staggered but still severe unemployment spells as not having received a "bad shock." It also characterizes all simultaneous unemployment spells as "bad
} 
have also found that this pattern is not present for households who rent their homes. Those couples move at relatively high rates that are insensitive to unemployment shocks.

\subsection{The Relationship Between Income Risk and House Value for Homeowners}

Given that our empirical setting matches the assumptions of the model, we turn to comparing the housing consumption and tenure choices of same- and different-occupation couples. Our primary approach will be to regress a measure of housing consumption (log house value for homeowners, log rent for renters, and an indicator variable for owning a house for the tenure choice) on a same-occupation indicator variable, $1_{\rho}$. Since the same-occupation variable proxies for the mean-preserving increase in risk, as measured by the correlation, $\rho$, a positive coefficient indicates that more risk leads to increased consumption. We include controls for the probability of the husband and wife becoming unemployed ( $p$ and $q$, respectively) and the probability that both would be unemployed if the risks were independent $(p q)$, since $p$ and $q$ contain information not just about risk, but also expected income. We include the squared unemployment rates for the husband and wife, $p^{2}$ and $q^{2}$, in case the relationship between the risk of unemployment and housing demand is nonlinear in a way that is not reflected in the model. We control for family income, $Y$, the share of the income earned by the husband, $s$, and year effects, $\delta_{t}$. Some specifications will include dummies for the MSA of residence $(k)$ interacted with year, $\delta_{k, t}$, as well as other covariates, $Z$, such as dummies for the number of people in the household, the number of children, the education of the husband and the wife, the age brackets for the husband and wife, and the husband's and wife's occupations. We estimate regressions of the form:

$$
\ln \left(P^{H}\right)_{i, t}=\left[\begin{array}{c}
\alpha_{1} 1_{\rho, i, t}+\alpha_{2} p_{i, t}+\alpha_{3} q_{i, t}+\alpha_{4} p q_{i, t}+\alpha_{5} p_{i, t}^{2}+\alpha_{6} q_{i, t}^{2}+\alpha_{7} s_{i, t} \\
+\gamma \ln (Y)_{i, t}+\varphi Z_{i, t}+\delta_{k, t}+\varepsilon_{i, t}
\end{array}\right]
$$

shocks," regardless of their severity. The short time period in which a household is observed in the SIPP makes a more precise measure of the severity and timing of dual unemployment difficult to obtain. 
on a sample of homeowners from the IPUMS for household $i$ in year $t .^{20}$

Estimating equation (16), we find that couples who share an occupation spend more on owner-occupied housing. The first column of Table 3.5 reports the results when the only additional covariates are the unemployment rate controls, log of family income, and the income share of the husband. Husbands and wives with the same occupation spend 4.3 percent more on housing (with a 0.4 percent standard error) than couples with different occupations. Non-mean preserving increases in risk, such as a higher risk of unemployment for either the husband, the wife, or both, reduce spending on housing, presumably because they lower expected future income. Current income is a good predictor of housing consumption, with an estimated elasticity of 0.625 (with a standard error of 0.003 ). The income share of the husband is insignificant in this specification.

The positive relationship between "same occupation", $1_{\rho}$, and housing spending, $\ln \left(P^{H}\right)$, is consistent with our theory and is not what would be expected from a precautionary saving model without commitment. However, it might merely reflect unobserved factors that are correlated with both $1_{\rho}$ and $\ln \left(P^{H}\right)$. To address this concern, we begin by controlling for MSA of residence in each year and a host of demographic characteristics. For example, by including MSA $\times$ year dummies and thus comparing housing spending for same- and different-occupation homeowners within a metro area in a given year, we control for the possibility that same-occupation couples may tend to locate in areas with high housing prices. The resulting estimates can be found in the second column of Table 3.5. Even with these controls - which allow us to rule out the effect of some unobservable factors at the expense of some of our identifying variation - same-occupation couples buy houses that are on average 2.7 percent more expensive than other couples'. The estimated coefficient on

\footnotetext{
${ }^{20}$ This regression is similar in spirit to those in Carroll and Samwick $(1997,1998)$. Those papers quantify precautionary saving by regressing measures of permanent and transitory income risk, as well as a variety of controls, on various measures of household wealth. Other papers take a similar approach in the housing context. Those empirical studies find a negative relationship between income risk and home ownership (DiazSerrano (2005), Haurin (1991), Robst et al. (1999)). Prior evidence on housing spending is ambiguous. Haurin and Gill (1987) find that military husbands' incomes positively affect their housing spending but their wives' incomes (which they argue are more uncertain) do not. Haurin (1991) examines the effect of income risk on house spending, and fails to find a statistically significant effect.
} 
the husband's income share becomes positive with the additional controls, indicating that more inequity in the couple's earnings is correlated with higher housing spending. ${ }^{21}$ The estimated coefficient on family income falls because the added demographic characteristics proxy for the household's permanent income.

Next, to control for the possibility that same-occupation couples are more prevalent in occupations that have a strong unobservable preference for housing, we include dummy variables for each spouse's occupation. Once we remove the effect of either spouse's occupation on housing consumption, does sharing an occupation further increase that consumption? In other words, do a dual-doctor and a dual-lawyer couple together spend more on owned housing than two doctor/lawyer couples? This regression implicitly assumes that the household's occupation-based taste for housing is simply the sum of each spouse's individual preference, as estimated from the sample of different-occupation couples.

These results are reported in the third column of Table 3.5. The new coefficient on "same occupation" implies that, controlling for each spouse's occupation, MSA $\times$ year effects, and a variety of demographics, same-occupation couples spend 2.1 percent (0.4 percent standard error) more on their houses than do different-occupation couples. Table 3.3 notes that sameoccupation couples have an 18 percentage point higher correlation in unemployment risk, so simple extrapolation gives an elasticity of house spending with respect to the unemployment correlation of $0.12(0.021 / 0.18)$. A 10 percentage point rise in a couple's unemployment correlation would yield a 1.2 percent increase in spending on owner-occupied housing. The unemployment rate and income controls decline in magnitude and significance with the addition of the occupation dummies, which is not surprising since much of the variation in unemployment rates is across occupation (with the remainder being within occupation over time), and income is correlated with occupation.

\footnotetext{
${ }^{21}$ This result is economically quite large; increasing the head's income share by one standard deviation (0.17) leads a household to spend almost 2 percent more on housing. While income share might be a measure of risk, it might also merely reflect the possibility that people who like to spend money pair up with spouses who make a lot of it. Therefore, we use the income share variable as a control and focus on the same-occupation variable as a much better identified measure of risk.
} 
These results are robust to using "same industry" as our proxy for couples' unemployment correlation. We have replicated the analysis using the IPUMS 1950 constant industry definitions, and imputing unemployment rates based on the husband's and wife's industries. As an example, we report one set of these replications in column 4. This column corresponds to the specification in column 3, replacing occupation variables with industry ones. All else equal, home-owning couples that share the same industry spend 5.6 percent more on housing. Since the difference in unemployment correlation between same- and different-industry households is also 0.18 , the elasticity of house spending with respect to unemployment correlation is $0.31(0.056 / 0.18)$.

One potential concern is that sharing the same occupation is a proxy for similarity in general, and the kind of people who choose similar spouses have a certain preference for housing. However, similarity per se does not seem to account for our findings. In regressions that we do not report, we have controlled for other dimensions on which spouses can be the same, namely age (in ranges) and education. While these variables occasionally have a statistically significant effect on housing spending, the sign of this impact is not uniform. Furthermore, including these variables has almost no effect on the estimated same-occupation coefficient.

Indeed, this baseline result is remarkably robust in a number of dimensions. In Table 3.6, we examine the relationship between "same occupation" and housing spending for different subsamples. We do this both to show that the result is generally applicable across the population, but also to ascertain that "same occupation" is not spuriously correlated with an observable characteristic. The reported coefficients are the estimated "same occupation" effects from regressions analogous to the one reported in the third column of Table 3.5.

In the first row of Table 3.6, we split the sample by decade, running separate regressions for 1980, 1990, and 2000. Our finding is not restricted to any particular time period. Sameoccupation homeowners spend from 1.7 to 2.3 percent more on housing than do differentoccupation households within the same MSA when controlling for income, occupation, and 
demographic characteristics.

The "same occupation" effect also is not limited to any particular age or education group. However, the magnitude of the effect of a higher correlation in unemployment risk on housing spending for homeowners is significantly bigger for same-occupation households where the husband is under age 45 or where neither of the spouses have had any postsecondary schooling. Both of these groups are likely to be more sensitive to unemployment shocks: the young because more of their wealth is in human capital; the less-educated because they have fewer resources to maintain their permanent income after an unemployment spell or because their job mobility is lower. In addition, households whose incomes are above the sample median have a smaller, and statistically insignificant, "same occupation" effect. Instead, relatively low-income families are much more sensitive to unemployment risk.

Finally, we split the sample based on the division of labor income between husband and wife. If one spouse receives little wage income, their unemployment risk potentially is not very relevant for the economic well-being of the household, and the unemployment risk of the primary wage-earner similarly is more important. By the same logic, the correlation in unemployment risk between spouses when one of them does not make very much money should be less of a factor in the housing decision. We test this relationship by comparing the estimated "same occupation" effect for households where the husband earns between 40 and 80 percent of the total labor income to those with more unequal division of earnings. The 40/80 cutoffs are approximately one standard deviation above and below the mean husband's share of income. Consistent with our expectations, we find sharing the same occupation has a larger effect on housing spending when the distribution of income between spouses is more equal.

The theory developed in Section 2 suggests that a positive relationship between risk and housing consumption should be present only when moving costs are high. This allows a more refined test of our hypothesis, where we test whether the interaction of adjustment costs and same-occupation status is positive while controlling separately for the direct ef- 
fects of adjustment costs and sharing the same occupation. That is, does the difference in housing consumption between same- and different-occupation homeowners grow as transaction costs rise? This refinement can be used to rule out the possibility that same-occupation couples spend more on housing because they have an unobservable taste for housing, as long as that taste is not confined only to high adjustment cost households. Similarly, if the increased housing spending by same-occupation couples reflects precautionary saving invested in owner-occupied housing, there is no reason to believe that precautionary saving in housing should be largest for households who are less likely to move.

One source of variation in adjustment costs comes from the probability of moving. Households that are likely to move soon for exogenous demographic reasons have a lower effective cost of a forced move than households who planned never to move. For households who were planning to move, a bad income shock merely accelerates the timing of a move that was going to happen soon anyway. While there is some cost to changing the timing of a move, it is presumably much smaller than the transaction cost of the move itself. In the extreme, a household that was about to move anyway does not face any additional housing transaction cost from unemployment. Conversely, the transaction cost is largest for a household that planned never to move; in that case, a forced move is a net new transaction cost. As a result, the effective transaction cost is declining in the likelihood of a move. The tendency of same-occupation couples to spend more on housing (relative to different-occupation couples) should be stronger when the exogenous probability of moving is lower.

In our consumption commitments framework, we would expect a positive coefficient on $1_{\rho}$ and a negative coefficient on $P($ move $) \times 1_{\rho}$. To test this hypothesis, we use an exogenous measure of the likelihood of moving based on the average rate of moving among couples of similar age, education, and presence of children. The construction of this measure is detailed in Section 3.1. We re-estimate equation (16), adding the interaction of our imputed probability of moving with "same occupation," $P($ move $) \times 1_{\rho}$, as well as $P$ (move) by itself as a control. The identifying assumption underlying this regression is that any difference 
between same- and different-occupation couples in the unobservable preference for housing is uncorrelated with the moving rate of similar households, after controlling separately for each of the household attributes we use to impute the probability of moving, and other household characteristics.

The second column of Table 3.7 reports the results of this regression. (The first column of this table merely repeats the results of the fully saturated regression from the third column of Table 3.5.) The estimated coefficient on $1_{\rho}$ in the second column corresponds to the case where the household expects never to move and thus faces the largest possible transaction costs. Consistent with our theory, this coefficient is positive and higher than in the first column, rising from 0.021 to 0.034 (0.007). The interaction between same-occupation and the probability of moving is negative and significant, at $-0.088(0.039)$. Thus, increasing risk does not increase housing spending when the probability of moving is high (and therefore the effective transaction cost is low). The standard deviation in the probability of moving for owners is 0.32 , so the precautionary motive dominates (the coefficient on "same occupation" becomes negative) for moving rates that are 0.86 standard deviations above the mean. ${ }^{22}$ Consistent with our theory, the empirical results show that when effective moving costs are low, households behave as would be predicted by a precautionary saving model without commitment, in that a mean-preserving spread in risk reduces housing spending. But when effective moving costs are high, housing spending rises with risk.

\subsection{The Relationship Between Income Risk and Rent for Renters}

A more obvious source of variation in moving costs stems from the tenure choice, as home renters face much lower moving costs than homeowners. As a result we should observe a weaker relationship between risk and housing consumption for home renters than for homeowners. Indeed, if renters' moving costs are low enough, greater risk should lead to lower

\footnotetext{
${ }^{22}$ The "same occupation" effect turns negative $(0.034-P($ move $) \times 0.088<0)$ when $P($ move $)>0.39$. That is 0.86 standard deviations above the mean $((0.39-0.11) / 0.32)$. To get a sense of the scaling, at the mean, a home-owning household expects to move every nine years (1.0/0.11). At a probability of moving 0.86 standard deviations above the mean, the expected length-of-stay is two years $(1 /(0.11+0.39))$.
} 
spending on rent. Also, variation in transactions costs stemming from the exogenous probability of moving should make little difference for renters, since they face low moving costs whether or not they plan to move.

We find that for renters, a mean-preserving increase in risk has no effect on the demand for rental housing. This result is reported in the third column of Table 3.7, which replicates the regression in the first column for a sample of renters, replacing $\log$ (house value) with $\log ($ rent $)$ as the explanatory variable. The estimated coefficient on the same-occupation variable is basically zero, at -0.002 , and not statistically significant. By contrast, note from the first column that same-occupation couples spend significantly more on owner-occupied housing than different-occupation couples. The difference between the same-occupation effect for owners and renters is 0.023 , and is statistically significant at the 95 percent confidence level. ${ }^{23}$ Finding different effects for owners and renters suggests that consumption commitments rather than unobserved attributes explain the tendency of same-occupation couples to spend more on housing. If sharing an occupation were merely a signal of an unobservable preference for housing, renters who share an occupation should rent more expensive homes than renters who do not and the difference between the estimated coefficients on "same occupation" for owners and renters should be small.

The fourth column of Table 3.7 presents a regression which adds both $P$ (move) and a $P($ move $) \times 1_{\rho}$ interaction to the regression predicting $\log ($ rent $)$ in the third column. This regression specification is identical to the one shown in the second column, with $\log (\mathrm{rent})$ replacing $\log ($ house value) as the explanatory variable. The impact of "same occupation" alone is negative but insignificant. The interaction variable has a positive coefficient but is also statistically insignificant. However, both of these coefficients are statistically significantly different from their analogs for owners in column 2. Since renters face low transaction costs regardless of whether or not they plan to move, we would not expect the relationship

\footnotetext{
${ }^{23}$ We tested the null that the same-occupation coefficient was the same for renters and owners by stacking the observations and fully interacting all variables with a renter dummy. The null was whether "same occupation" $\times$ renter was equal to zero.
} 
between risk and consumption to be affected by the probability of moving.

\subsection{The Relationship Between Income Risk and Home Ownership}

Another implication of the model is that renting becomes relatively more appealing as the correlation between spouses' unemployment events increases. Knowing that simultaneous unemployment - and therefore moving - is more likely for them, same-occupation couples may adapt by renting, rather than owning, in order to save on the costs of future moves. The fifth column of Table 3.7 confirms that same-occupation couples are less likely to own their homes. This column repeats the regressions in the first and third columns, replacing the explanatory variables with an indicator that takes the value of one if the household owns their home. The increased sample size reflects the fact that this regression includes both homeowners and renters. For this linear probability model, the estimated coefficient on "same occupation" is -0.014 (0.003), so same-occupation couples have a 1.4 percentage point lower rate of home ownership relative to different-occupation households, ceteris paribus. Since those same-occupation couples have an 18 percentage point higher unemployment correlation, the elasticity of home ownership with respect to the correlation in risk is -0.078 $(-0.014 / 0.18)$.

This result also helps to confirm that the relationship between risk and housing spending represents housing consumption and not precautionary saving invested in a housing asset. If precautionary wealth were invested in housing, increasing risk would make households more likely to buy and less likely to rent their homes. ${ }^{24}$ By contrast, our model implies that increasing risk would make households more likely to rent and less likely to own their homes. ${ }^{25}$

\footnotetext{
${ }^{24}$ Buying a larger house is an inefficient way to save. The return on housing is comprised of the capital gain plus the rental value of living in the house (the dividend). Homeowners are constrained to consume their entire dividend, so buying a bigger house as a form of saving forces the household into overconsuming housing in the first period, leaving a net-of-the-consumption-value return on the owner-occupied house that is lower than an alternative investment (such as rental housing).

${ }^{25}$ This own/rent result also rejects other alternatives that induce households with greater risk to invest in housing. One such story is that the housing asset is protected in bankruptcy, so if a same-occupation couple is more likely to file for bankruptcy, they should purchase more housing. If that hypothesis explained the results, riskier households should be more likely to own their homes and not rent, which is contrary to the
} 
As we noted earlier, our model predicts that same-occupation households will have a relatively stronger preference for renting only in the presence of significant moving costs. We test this refinement in the sixth column of Table 3.7 by adding as covariates the interaction of the imputed probability of moving and the same-occupation indicator, $P($ move $) \times 1_{\rho}$, as well as the imputed probability of moving alone, $P$ (move). This column merely repeats the regressions shown in columns two and four, with the home ownership indicator variable as the explanatory variable.

Since effective moving costs are highest for households that are unlikely to move for exogenous demographic reasons, we would expect the difference between same- and differentoccupation couples in the propensity to own should be most negative for these households. As the probability of moving rises, the difference between same- and different-occupation couples should become less negative, so $P($ move $) \times 1_{\rho}$ should have a positive coefficient. This prediction stands in contrast to the expected effect of $P$ (move) on tenure choice. Since frequent movers, whether or not spouses share an occupation, pay higher expected moving costs, they should be more likely to rent. Therefore, $P$ (move) should have a negative coefficient.

The sixth column of Table 3.7 presents results that match the predictions of the model. In the first row, the estimated coefficient on "same occupation" corresponds to households that implicitly expect never to move. The point estimate of $-0.027(0.005)$ is nearly twice as large as the average effect across all households, which is the coefficient reported in the fifth column. Unsurprisingly, frequent movers tend to rent as indicated by the negative and significant coefficient in the second row. In the third row, the interaction term shows a positive and significant coefficient. As the probability of moving increases, the difference in the propensity for home ownership between same- and different-occupation households becomes less negative. Simple extrapolation from the point estimate of $0.084(0.026)$ shows that the gap between same- and different-occupation couples is eliminated when the probability of evidence in the fifth column of Table 3.7 . 
moving is roughly 32 percent, equivalent to a three-year expected stay.

It is useful to consider whether the overall pattern of results we observe in Tables 3.5 and 3.7 could be generated by an unobserved taste for housing by same-occupation couples, combined with endogenous self-selection into home ownership. First, suppose sameoccupation couples had a higher mean unobserved taste for housing than different-occupation couples, so their preference distribution were shifted to the right. That form of heterogeneity would cause same-occupation homeowners to spend more on their homes. But it would also suggest, counterfactually, that same-occupation renters would spend more on rent. If same-occupation couples merely had a preference for home ownership, it could explain why same-occupation couples have higher spending on owner-occupied housing but not rental housing. But that model would predict that same-occupation couples would be more likely to own their houses, which is contradicted by the data.

However, if same-occupation couples had the same mean but higher variance in the unobserved preference for housing than different-occupation couples, it could explain more of the empirical regularities we find. Since same-occupation households would have thicker preference tails - they either love housing or they hate it - same-occupation households who loved housing would own and also spend more than the more neutral different-occupation households. Those same-occupation households who disliked housing would rent and not spend much on rent relative to different-occupation households. In addition, depending on the clearing price of owned housing, it is possible that more different-occupation than sameoccupation households prefer owning. In that case, same-occupation households would have a lower rate of home ownership. If this explanation is true, it implies a straightforward and testable prediction. The residuals for the same-occupation, home-owning couples in the housing demand regression should be more right-skewed than those for the differentoccupation couples. Similarly, the residuals for the same-occupation renting couples in the rent regression should be more left-skewed. In our data, there is no distinguishable difference in skewness in residuals between same- and different-occupation couples, so variation in the 
second moment of unobserved taste for housing cannot explain our results. Furthermore, it seems unlikely that any difference between same- and different-occupation couples in the taste for housing is present only for households with a low exogenous probability of moving. This would have to be true to explain the pattern of coefficients on the interaction between "same occupation" and the imputed probability of moving.

\subsection{Consumption Commitments and Unemployment Insurance}

Our final empirical test examines how the generosity of unemployment insurance (UI) affects the relationship between "same occupation" and housing spending. More generous UI effectively reduces the size of shocks to permanent income since it affords the unemployed the ability to set a higher reservation wage in their job search (Feldstein and Poterba (1984)). A theory incorporating consumption commitments predicts a positive relationship between "same occupation" and housing spending only when the household experiences a loss large enough to induce moving. Therefore, the difference in housing spending between same- and different-occupation couples should decrease (become less positive) when unemployment insurance becomes more generous. By contrast, a model of precautionary saving without commitment would predict that increasing risk reduces spending less when UI is more generous; the difference in housing spending between same- and different-occupation couples should increase (become less negative) as UI becomes more generous. ${ }^{26}$

There are several sources of variation in the generosity of UI. While state UI programs typically compensate the unemployed for up to 50 percent of lost wages up to a cap, the level of the cap and the replacement rate schedule vary across states, over time, and according to the number of dependent children. In addition, the generosity of UI is a nonlinear function of income: the replacement rate remains constant until income reaches the cap, at which point it declines with income. ${ }^{27}$ Lastly, this nonlinearity in the replacement rate implies

\footnotetext{
${ }^{26}$ e.g., Engen and Gruber (2001).

${ }^{27}$ Once income exceeds the cap, the absolute benefit amount remains level at 50 percent of the cap amount but is declining as a percentage of income.
} 
that the share of income earned by each spouse influences the couple's total replacement rate in the event that both spouses lose their jobs. For example, if both spouses earn exactly the cap amount and both become unemployed, they collectively will receive 50 percent of their former wages. But if one spouse earns twice the cap amount and the other earns almost nothing - total family income is the same but its allocation is not - the family can at best replace 25 percent of their former income.

To implement this test, we calculate UI replacement rates for each spouse using the unemployment insurance calculator developed by Cullen and Gruber (2000) and extended by Chetty (2004). ${ }^{28}$ Since the calculator contains information about UI since 1984, we restrict our sample to 1990 and 2000. We calculate the household's replacement rate as the average replacement rate for each spouse, weighted by their respective income shares. Then we interact this measure of the household's replacement rate with the same-occupation, unemployment rate, income share and other control variables from equation (16), and test whether the coefficient on the "same occupation" $\times$ replacement rate interaction is negative. Assuming that the variation in UI generosity is uncorrelated with differences between sameand different-occupation couples in the unobservable demand for housing or home ownership, then this interaction term provides a clean test of the consumption commitments theory.

We make one further refinement to the empirical specification. Although the model in Section 2 assumed that husbands and wives earned the same amount, in practice one member of the household might have significantly greater income than the other. In that case, the possibility of unemployment for the low-income spouse poses a smaller risk to the household than would be implied by their unemployment rates. To correct this mismeasurement, we weight the unemployment and same-occupation variables by the husband's and wife's shares of family income. In Table 3.1, on average husbands earn 62.1 percent of household income when both spouses are working full-time. Labelling the husband's share of income $s$ and the wife's share $(1-s)$, the husband's unemployment risk controls become $p s$ and

\footnotetext{
${ }^{28}$ We are grateful to Raj Chetty for letting us use his UI calculator and benefit data.
} 
$p^{2} s^{2}$; the wife's, $q(1-s)$ and $q^{2}(1-s)^{2}$; and, for both, $p q s(1-s)$. The same-occupation indicator variable, $1_{\rho}$, also based on the interaction of both spouses' attributes, is multiplied by both income shares, $1_{\rho} s(1-s)$. We also control for the husband's income share and the husband's $\times$ wife's income shares independently. While including these interaction terms in the earlier regressions also would have been justified, in practice doing so makes little difference in the estimated coefficients and their statistical significance, so we opted for a more easily interpretable specification. However, the UI replacement rate is also a function of $s$, so omitting it in this context would lead to a biased estimate of the interaction of "same occupation" with UI generosity.

We estimate the following regression on the sample of homeowners, where $R$ denotes the replacement rate and $g\left(p_{i, t}, q_{i, t}, s_{i, t}\right)=p s_{i, t}+q(1-s)_{i, t}+p q s(1-s)_{i, t}+(p s)_{i, t}^{2}+(q s)_{i, t}^{2}$ :

$$
\ln \left(P^{H}\right)_{i, t}=\left[\begin{array}{c}
{\left[\beta_{1} 1_{\rho, i, t}+\beta_{2}\left(1_{\rho, i, t} \times R_{i, t}\right)\right] s(1-s)_{i, t}} \\
+\beta_{3} g\left(p_{i, t}, q_{i, t}, s_{i, t}\right)+\beta_{4}\left(g\left(p_{i, t}, q_{i, t}, s_{i, t}\right) \times R_{i, t}\right) \\
+\beta_{5} s_{i, t}+\beta_{6}\left(s_{i, t} \times R_{i, t}\right)+\beta_{7} s_{i, t}\left(1-s_{i, t}\right)+\beta_{8}\left(s_{i, t}\left(1-s_{i, t}\right) \times R_{i, t}\right) \\
+\gamma_{1} \ln (Y)_{i, t}+\gamma_{2}\left(\ln (Y)_{i, t} \times R_{i, t}+\varphi Z_{i, t}+\delta_{k, t}+\varsigma_{s, t}+\varepsilon_{i, t}\right.
\end{array}\right]
$$

This regression interacts the same occupation dummy from equation (16), as well as the unemployment rate, family income, and income share controls, with the household's replacement rate. Since this specification includes MSA $\times$ year dummies $\left(\delta_{k, t}\right)$, state $\times$ year dummies $\left(\varsigma_{s, t}\right)$, and income share controls, we are examining how same- and differentoccupation households respond differently to variation across states in their UI programs, while controlling for any state-level generosity that affects same- and different-occupation households equally.

We find that increasing the correlation in unemployment risk raises housing spending more for homeowners with lower UI replacement rates. Since the effect of the UI replacement rate may not be linear, we report three functional forms for the replacement rate, $R$ : an 
indicator for being in the bottom decile of the replacement rate by decade, an indicator for the bottom quartile, and a linear function of the replacement rate. We compute robust standard errors, clustered on state, year, and replacement rate segment. ${ }^{29}$ In the first column of the top panel of Table 3.8, which includes the entire set of covariates except the husbands' and wives' occupation dummies, the estimated same-occupation effect for the top 90 percent of households by replacement rate (the excluded group) is 0.077 (0.019). In order to evaluate the same-occupation effect at the mean, we need to multiply it by the average income shares of the husband and wife. Those averages are approximately $2 / 3$ and $1 / 3$, respectively, so multiplying the estimated coefficient by $2 / 9$ yields an estimate comparable to those in the previous tables. Here, the average same-occupation couple with a UI replacement rate in the top 90 percent spends an additional 1.7 percent more on housing than do different-occupation couples with similar replacement rates. Consistent with our predictions, the difference in spending on housing between same- and different- occupation couples is biggest in the lowest replacement rate decile. The second row of the first column reports how the difference in housing spending between same- and different occupation couples changes in the bottom replacement rate decile. Bottom-decile, same-occupation couples spend an additional 6.0 percent (1.8 percent standard error) more on housing relative to different-occupation couples in the same decile, net of any same/different occupation differences in spending for the top 90 percent. ${ }^{30}$ While we do not report the estimated coefficients on the interactions of the husband's and wife's unemployment rates with the replacement rate, in all cases higher risks of unemployment reduce housing spending more when UI replacement rates are very low.

\footnotetext{
${ }^{29}$ For the bottom-decile specification, the replacement rate segments are simply the bottom 10/top 90 percent ranges. Similarly, for the bottom-quartile specification, the segments are the bottom 25/top 75 percent ranges. In the linear specification, the segments are the linear portions of the UI replacement schedule. Each spouse can be on one of three sections: the spouse is ineligible $(R=0)$; the spouse's income is below or at the benefits maximum (typically this means $\mathrm{R}=0.5$, although the cap varies over time, across states, and by family structure); or the spouse's income is above the benefits maximum (typically, $0<\mathrm{R}<0.5$, depending on the state's cap). Of the six possible spousal combinations, five are populated with households in our data, and we cluster on those combinations interacted with year. The empty segment is both spouses having incomes above the benefits maximum.

${ }^{30} 6.0$ percent is calculated as the product of the estimated coefficient $(0.267)$ and the product of the average husband's and wife's income shares $(2 / 3 \times 1 / 3=2 / 9)$. The standard error is similarly adjusted.
} 
In column 2, a similar pattern is seen when we divide households into the top three quartiles and bottom quartile by replacement rate. The same-occupation couples in the top 75 percent spend 1.7 percent more on housing than do comparable different-occupation couples. Same-occupation couples in the bottom quartile spend an additional 3.3 percent more on housing than do bottom-quartile different-occupation households, all relative to the difference in spending between same- and different-occupation couples in the top three quartiles.

In the third column, the replacement rate enters linearly. Unlike in the previous columns, here a higher value for $R$ implies more generous UI, so we expect a negative coefficient. The first row corresponds to same-occupation couples with a zero replacement rate. They spend 4.5 percent $(0.203 \times 2 / 9,1.4$ percent standard error $)$ more on housing than comparable different-occupation couples. As the replacement rate increases, the difference in housing spending between same- and different-occupation couples falls. For each 10 percentage point increase in the replacement rate, the gap shrinks by 0.72 percentage points. In a sign that the replacement rate relationship is nonlinear, this interaction term is statistically significant only at the 91 percent confidence level.

The bottom panel repeats the estimation, but adds occupation dummies. In the first two columns, the estimated "same occupation" effect is about one-third smaller, but remains statistically significant. The estimated coefficients on the interaction terms, however, are only one-fourth their prior magnitude and no longer are statistically significant. Both coefficients of interest in the linear specification (column 3) are indistinguishable from zero.

\section{Conclusion}

This paper shows the surprising effect that consumption commitments can have on the role of risk in households' consumption decisions: households may increase consumption in response to increased risk. We illustrated this idea in the context of a dual-career household that faces unemployment risk and consumes housing. Suppose the household faces the 
risk of an income shock large enough that moving would be worthwhile. This household may purchase a house of roughly the size that it would want in the absence of the shock, since buying a smaller house initially would not spare it from moving in the event of the shock. By contrast, if a household faces the risk of an income shock that would not be large enough to induce moving, they must buy a house small enough to ensure sufficient non-housing consumption after they have paid for their committed housing consumption. In this context, a mean-preserving increase in risk that makes large shocks more likely and small shocks less so will increase housing consumption. This striking result is the opposite of what would be predicted by a precautionary saving model without commitment.

This result requires adjustment costs to be high enough to deter moving in all but the worst states. Therefore, it should not apply when moving costs are low, as they are for renters or those who expect to move soon. Furthermore, households with higher unemployment correlations - who are more likely to face shocks large enough to induce moving - should be more likely to consume housing with lower adjustment costs; they should rent rather than own their homes.

When we proxy for a mean-preserving increase in risk by whether a married couple shares the same occupation, which is a proxy for a higher correlation in unemployment risk, we find that this behavior is pervasive in the data. Controlling for each spouse's characteristics, including their individual occupations and probabilities of unemployment, we find that sameoccupation households spend relatively more on housing. As expected, this result is confined to homeowners, and is strongest for those owners who face effectively higher moving costs due to a lower exogenous probability of moving. Furthermore, same-occupation couples, compared to other couples, are relatively more likely to rent their homes, with this difference confined to households that are less likely to move for demographic reasons. Finally, sameoccupation couples spend relatively more on housing consumption compared to differentcareer couples when unemployment insurance is less generous. All of these patterns are consistent with households increasing housing consumption in the face of increased risk in 
the presence of moving costs.

Of course, our finding that commitments affect the relationship between risk and consumption does not deny the importance of prudence in generating precautionary saving. Rather, these offsetting motives operate in concert. Even so, the net positive effect of risk on consumption can be quite significant for many households. Simple calibrations suggest that the size of this net positive effect should be of roughly the same magnitude as the negative effect in a precautionary saving model without commitment. Empirically, for households with the highest moving costs, we estimate that an 18 percentage point increase in the unemployment risk correlation between spouses raises housing spending by 3.4 percent for households that never plan to move (from Table 3.7, column 2). That change in correlation corresponds to more than doubling the likelihood of joint unemployment (from 0.67 to 1.47 percent). Extrapolating, a one percentage point increase in the risk of dual unemployment would raise housing spending by 4.25 percent.

These findings are important, in part, because they illustrate that households do not necessarily behave in the manner predicted by the usual precautionary saving intuition. However, we have chosen to limit the scope of our analysis to a context that can be cleanly isolated in the data. The intuition in this paper extends beyond dual-career couples, unemployment risk, and housing consumption. It remains for future empirical work to show that greater risk in the face of consumption commitments can sometimes lead to lower saving or wealth, and for all types of households and consumption commitments. 


\section{A Appendix A: Proofs}

\section{A.1 Proof of Lemma 1}

The first order condition can be written as:

$$
0=\left[\begin{array}{c}
g^{\prime}\left(h_{1}\right)+(1-p-q+\phi)\left[-g^{\prime}\left(\frac{1}{2}\left(Y_{1}+2 Y_{2}^{E}-2 h_{1}\right)\right)\right] \\
+(p+q-2 \phi)\left[-g^{\prime}\left(\frac{1}{2}\left(Y_{1}+Y_{2}^{E}+Y_{2}^{U}-2 h_{1}\right)\right)\right] \\
+\phi\left[-g^{\prime}\left(\frac{1}{2}\left(Y_{1}+2 Y_{2}^{U}-2 h_{1}\right)\right)\right]
\end{array}\right]
$$

Implicit differentiation of (18) yields:

$$
\frac{d h_{1}}{d \phi}=\frac{g^{\prime}\left(\frac{1}{2}\left(Y_{1}+2 Y_{2}^{U}-2 h_{1}\right)\right)-2 g^{\prime}\left(\frac{1}{2}\left(Y_{1}+Y_{2}^{E}+Y_{2}^{U}-2 h_{1}\right)\right)+g^{\prime}\left(\frac{1}{2}\left(Y_{1}+2 Y_{2}^{E}-2 h_{1}\right)\right)}{\left[\begin{array}{c}
g^{\prime \prime}\left(h_{1}\right)+(1-p-q+\phi)\left[g^{\prime \prime}\left(\frac{1}{2}\left(Y_{1}+2 Y_{2}^{E}-2 h_{1}\right)\right)\right] \\
+(p+q-2 \phi)\left[g^{\prime \prime}\left(\frac{1}{2}\left(Y_{1}+Y_{2}^{E}+Y_{2}^{U}-2 h_{1}\right)\right)\right]+\phi\left[g^{\prime \prime}\left(\frac{1}{2}\left(Y_{1}+2 Y_{2}^{U}-2 h_{1}\right)\right)\right]
\end{array}\right]}
$$

The denominator of this expression is negative since $g^{\prime \prime}<0$. ( $g$ is assumed to be concave. $)$ The numerator will be positive if $g^{\prime \prime \prime}<0$. Therefore, $\frac{d h_{1}}{d \phi}>0$ if $g^{\prime \prime \prime}<0$. Similarly, the numerator will be zero if $g^{\prime}$ is linear, or equivalently if $g^{\prime \prime \prime}=0$. Therefore, $\frac{d h_{1}}{d \phi}=0$ if $g^{\prime \prime \prime}=0$. Finally, the numerator will be negative if $g^{\prime \prime \prime}>0$. Therefore, $\frac{d h_{1}}{d \phi}<0$ if $g^{\prime \prime \prime}>0$.

\section{A.2 Proof of Lemma 2}

If it is optimal to move only in the worst state of the world, then the problem can be described with the following first order conditions:

$$
\begin{gathered}
0=\left[\begin{array}{c}
\left(1-\alpha f_{1}\right)+(1-p-q+\phi)\left\{\left(-1+\alpha\left(Y_{1}+2 Y_{2}^{E}-2 h_{1}-f_{1}\right)\right)\right\} \\
+(p+q-2 \phi)\left[\left(-1+\alpha\left(Y_{1}+Y_{2}^{E}+Y_{2}^{U}-2 h_{1}-f_{1}\right)\right)\right] \\
+\phi\left[-1+\frac{\alpha}{2}\left(Y_{1}+2 Y_{2}^{U}-h_{1}-k-f_{1}\right)\right]
\end{array}\right] \\
0=\left[\begin{array}{c}
\left(1-\alpha h_{1}\right)(2-\phi)+(1-p-q+\phi)\left(-2+2 \alpha\left(Y_{1}+2 Y_{2}^{E}-2 h_{1}-f_{1}\right)\right) \\
+(p+q-2 \phi)\left(-2+2 \alpha\left(Y_{1}+Y_{2}^{E}+Y_{2}^{U}-2 h_{1}-f_{1}\right)\right) \\
+\phi\left[-1+\frac{\alpha}{2}\left(Y_{1}+2 Y_{2}^{U}-h_{1}-k-f_{1}\right)\right]
\end{array}\right] .
\end{gathered}
$$

These first order conditions can be simplified:

$$
\begin{aligned}
& 0=Y_{1}\left[1-\frac{1}{2} \phi\right]+Y_{2}^{E}[2-p-q]+Y_{2}^{U}[(p+q-\phi)]-\frac{1}{2} k \phi+f_{1}\left[-2+\frac{1}{2} \phi\right]+h_{1}\left[-2+\frac{3}{2} \phi\right] \\
& 0=Y_{1}\left[2-\frac{3}{2} \phi\right]+2 Y_{2}^{E}[2-p-q]+Y_{2}^{U}[2 p+2 q-3 \phi]-\frac{1}{2} k \phi+f_{1}\left[-2+\frac{3}{2} \phi\right]+h_{1}\left[-6+\frac{9}{2} \phi\right] .
\end{aligned}
$$

The optimal levels of consumption can be found by solving this system of equations to yield:

$$
\begin{aligned}
& f_{1}^{*}=\frac{1}{4}\left(Y_{1}+2 Y_{2}^{E}+(p+q)\left(Y_{2}^{U}-Y_{2}^{E}\right)-k \phi\right) \\
& h_{1}^{*}=\frac{1}{4}\left(Y_{1}+Y_{2}^{E}(2-p-q)+Y_{2}^{U}(p+q)-k \phi\right)+\phi \frac{[2-p-q]\left(Y_{2}^{E}-Y_{2}^{U}\right)+k(1-\phi)}{[4-3 \phi]} .
\end{aligned}
$$


Note that there is, depending upon the definition, either precautionary saving or no precautionary saving in food consumption. Food consumption in the first period falls with $\phi$, the measure of the mean-preserving increase in risk. In this sense, there is precautionary saving. However, food consumption is exactly equal to one quarter of expected net income when expected moving costs are included in the measure of income.

Differentiating the expression for optimal consumption with respect to $\phi$ gives:

$$
\frac{d h_{1}}{d \phi}=\frac{18\left(Y_{2}^{E}-Y_{2}^{U}\right)\left(1-\frac{1}{2} p-\frac{1}{2} q\right)-\frac{9}{2} \phi k+\frac{27}{16} \phi^{2} k}{\left[6-\frac{9}{2} \phi\right]^{2}}
$$

Note that $\frac{d h_{1}^{*}}{d \phi}>0$ if and only if

$$
\frac{2[2-p-q]\left(Y_{2}^{E}-Y_{2}^{U}\right)}{\phi\left(1-\frac{3}{8} \phi\right)}>k .
$$

Since

$$
[2-p-q]>\phi\left(1-\frac{3}{8} \phi\right)
$$

the condition will be satisfied whenever

$$
2\left(Y_{2}^{E}-Y_{2}^{U}\right)>k
$$

This can be shown most simply by noting that the decision in the dual unemployment state to move necessarily means having a lower level of housing consumption relative to not moving. To be optimal, moving must allow for a higher level of food consumption than not moving:

$$
\begin{aligned}
\frac{1}{2}\left(Y_{1}+2 Y_{2}^{U}-k-f_{1}-h_{1}\right) & >Y_{1}+2 Y_{2}^{U}-f_{1}-2 h_{1} \\
0 & >\frac{1}{2} Y_{1}+Y_{2}^{U}+\frac{1}{2} k-\frac{1}{2} f_{1}-\frac{3}{2} h_{1} .
\end{aligned}
$$

Note that initial food and housing consumption when it is optimal to move only in the worst state, $\left\{f_{1}^{*}, h_{1}^{*}\right\}$, will be greater than the level of initial housing or food consumption, $\underline{\mathrm{c}}_{1}$, that would be chosen if the dual-unemployment state obtained with certainty and if the household were required to move in the dual-unemployment state. Therefore,

$$
f_{1}^{*}, h_{1}^{*}>\underline{\mathrm{c}}_{1} \equiv \frac{1}{4}\left(Y_{1}+2 Y_{2}^{U}-k\right) .
$$

Note that the inequality (19) is satisfied with equality if $f_{1}^{*}=h_{1}^{*}=\underline{\mathrm{c}}_{1}$ and is satisfied strictly for all greater values. Therefore,

$$
\frac{d h_{1}}{d \phi}>0
$$




\section{References}

[1] Brueckner, Jan. "Consumption and Investment Motives and the Portfolio Choices of Homeowners," Journal of Real Estate Finance and Economics, September 1997, 15, $159-180$.

[2] Browning, Martin; Crossley, Thomas F. "Shocks, Stocks and Socks: Smoothing Consumption Over a Temporary Income Loss," CAM Working Paper, March 2004.

[3] Campbell John Y.; Cocco, Joao F. "Household Risk Management and Optimal Mortgage Choice," Quarterly Journal of Economics, November 2003, 118(4), 1449-1494.

[4] Carroll, Christopher D.; Samwick, Andrew A. "The Nature of Precautionary Wealth," Journal of Monetary Economics, September 1997, 40(1), 41-71.

[5] Carroll, Christopher D.; Samwick, Andrew A. "How Important Is Precautionary Saving?" Review of Economics and Statistics, August 1998, 80(3), 410-419.

[6] Chetty, Raj. "Consumption Commitments, Unemployment Durations, and Local Risk Aversion," NBER Working Paper \#10211, January 2004.

[7] Chetty, Raj; Szeidl, Adam. "Consumption Commitments and Asset Prices," Harvard University Working Paper, February 2004.

[8] Cullen, Julie B.; Gruber, Jonathan. "Does Unemployment Insurance Crowd Out Spousal Labor Supply?" Journal of Labor Economics, 2000, 18(3), 546-572.

[9] Davidoff, Thomas. "Maintenance and the Home Equity of the Elderly," UC Berkeley Working Paper, February 2004.

[10] Davidoff, Thomas. "Labor Income, Housing Prices and Homeownership," Journal of Urban Economics, forthcoming, 2005.

[11] Diaz-Serrano, Luis. "Labor Income Uncertainty, Skewness and Homeownership: A Panel Data Study for Germany and Spain." Journal of Urban Economics, July 2005, 58(1), 156-176.

[12] Drèze, Jacques H.; Modigliani, Franco. "Consumption Decisions Under Uncertainty," Journal of Economic Theory, December 1972, 5(3), 308-335

[13] Engen, Eric M.; Gruber, Jonathan. "Unemployment Insurance and Precautionary Saving," Journal of Monetary Economics, June 2001, 47(3), 545-579.

[14] Feldstein, Martin; Poterba, James. "Unemployment Insurance and Reservation Wages." Journal of Public Economics, February-March 1984, 23(1-2), 141-167.

[15] Flavin, Marjorie. "Owner-Occupied Housing in the Presence of Adjustment Costs: Implications for Asset Pricing and Nondurable Consumption," UCSD Working Paper, October 2001.

[16] Flavin, Marjorie; Yamashita, Takashi. "Owner-Occupied Housing and the Composition of the Household Portfolio," American Economic Review, March 2002, 91(1), 345-362.

[17] Fratantoni, Michael C. "Homeownership and Investment in Risky Assets," Journal of Urban Economics, July 1998, 44(1), 27-42.

[18] Fratantoni, Michael C. "Homeownership, Committed Expenditure Risk, and the Stockholding Puzzle," Oxford Economic Papers, April 2001, 53(2), 241-259.

[19] Goetzmann, William. "The Single Family Home in the Investment Portfolio," Journal of Real Estate Finance and Economics, May 1993, 6(3), 201-222.

[20] Goodman, John; Ittner, John. "The Accuracy of Home-Owners' Estimates of House Value," Journal of Housing Economics, December 1992, 2(4), 339-357. 
[21] Gyourko, Joseph; Tracy, Joseph. "Using Home Maintenance and Repairs to Smooth Variable Earnings," Wharton Real Estate Center Working Paper \#411, March 2003.

[22] Haurin, Donald R. "Income Variability, Homeownership, and Housing Demand," Journal of Housing Economics, 1991, 1(1), 60-74.

[23] Haurin, Donald R.; Gill, H. Leroy. "Effects of Income Variability on the Demand for Owner-Occupied Housing," Journal of Urban Economics, September 1987, 22(2), 136151.

[24] Henderson, J. Vernon.; Ioannides, Yannis. M. "A Model of Housing Tenure Choice," American Economic Review, March 1983, 73(1), 98-113.

[25] Hendershott, Patric; Slemrod, Joel. "Taxes and the User Cost of Capital for OwnerOccupied Housing," AREUEA Journal, Winter 1983, 10(4), 375-393.

[26] Kimball, Miles S. "Precautionary Saving in the Small and in the Large," Econometrica, 1990, 58(1), 53-73.

[27] Leland, Hayne E. "Saving and Uncertainty: The Precautionary Demand for Saving," Quarterly Journal of Economics, August 1968, 82(3), 465-473

[28] Postlewaite, Andrew; Samuelson, Larry; Silverman, Dan. "Consumption Commitments and Preferences for Risk," University of Michigan Working Paper, April 2004.

[29] Poterba, James. "Tax Subsidies to Owner-Occupied Housing: An Asset Market Approach," Quarterly Journal of Economics, November 1984, 99(4), 729-752.

[30] Robst, John; Deitz, Richard; McGoldrick, KimMarie. "Income Variability, Uncertainty, and Housing Tenure Choice," Regional Science and Urban Economics, March 1999, $29(2), 219-229$.

[31] Sandmo, Agmar. "The Effect of Uncertainty on Saving Decisions," Review of Economic Studies, July 1970, 37(3), 353-360.

[32] Sinai, Todd; Souleles, Nicholas. "Owner Occupied Housing as a Hedge Against Rent Risk," Quarterly Journal of Economics, May 2005, 120(2), 763-789.

[33] Warren, Elizabeth; Tyagi, Amelia Warren. The Two-Income Trap, New York: Basic Books, 2003. 
Figure 2.1:

Indirect Utility of Wealth in the Second Period Given Housing Consumption in the First Period

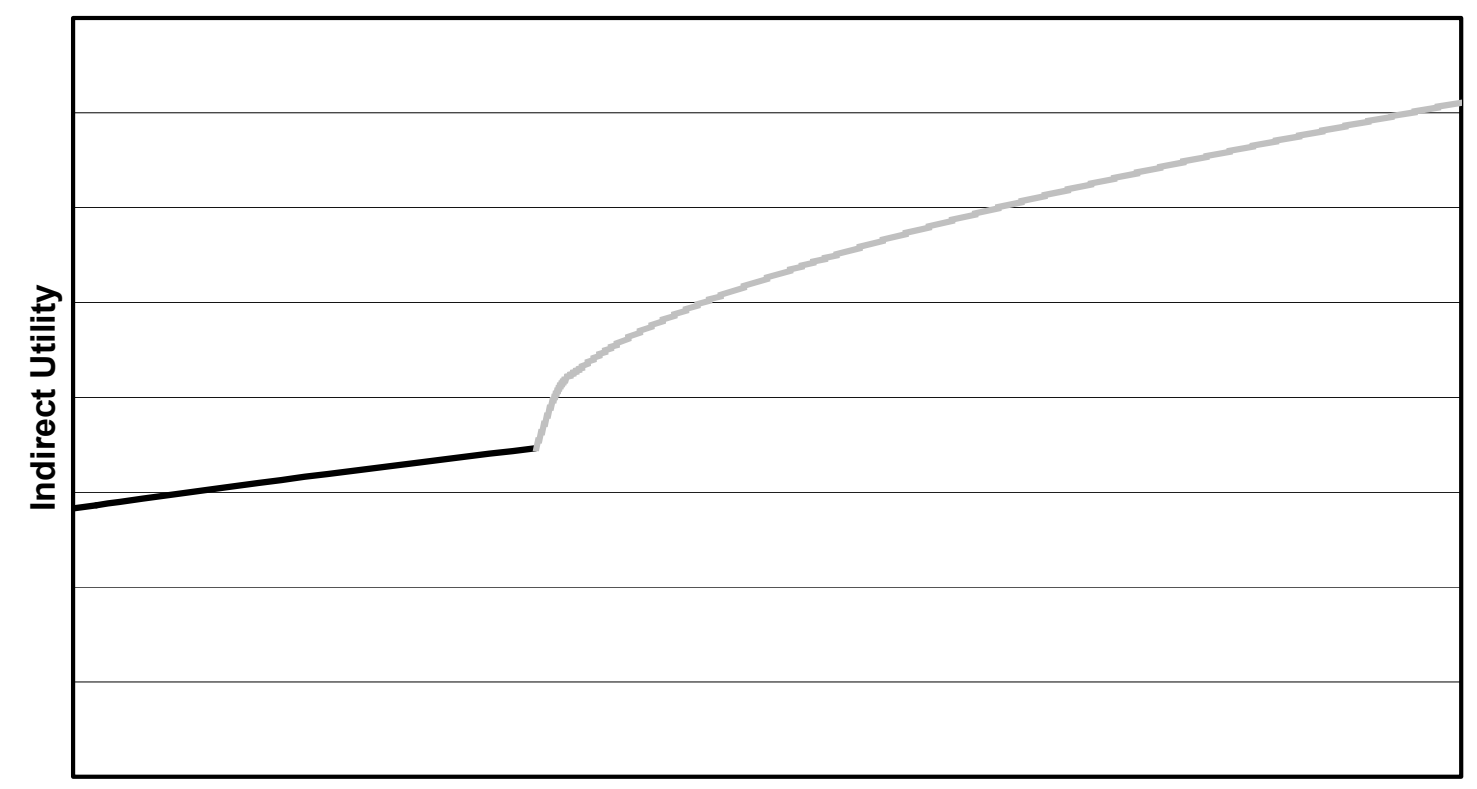

Wealth

Notes: This figure plots the indirect utility in the second period, assuming that wealth is optimally allocated between food and housing. Not to scale. 
Figure 2.2:

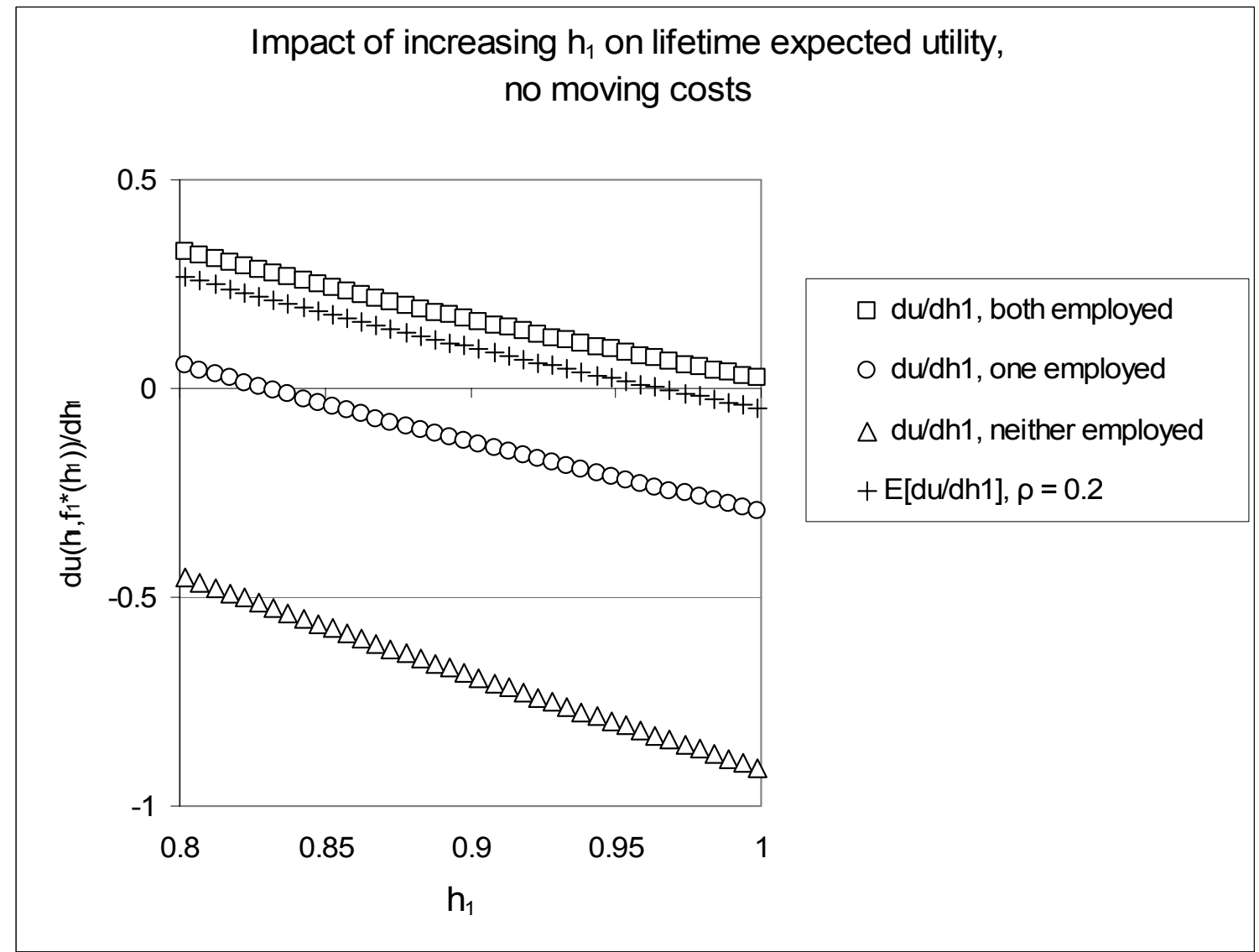

Notes: This figure plots the marginal lifetime utility of first-period housing consumption against firstperiod housing consumption. There are no moving costs, so $\mathrm{k}=0$. First-period income, $\mathrm{Y}_{1}=2$; second period income for a given spouse is either $\mathrm{Y}_{2}^{\mathrm{E}}=1$ with probability $1-\mathrm{p}=1-\mathrm{q}=0.9$ or $\mathrm{Y}_{2}{ }^{\mathrm{U}}=0.5$ with probability $\mathrm{p}=\mathrm{q}=0.1$. As a result, total household second-period income is $2,1.5$, or 1 . The correlation of the household's unemployment shocks is $\rho=0.2$. Lifetime utility is given as the sum of log food and $\log$ housing consumption in periods 1 and 2 . 
Figure 2.3:

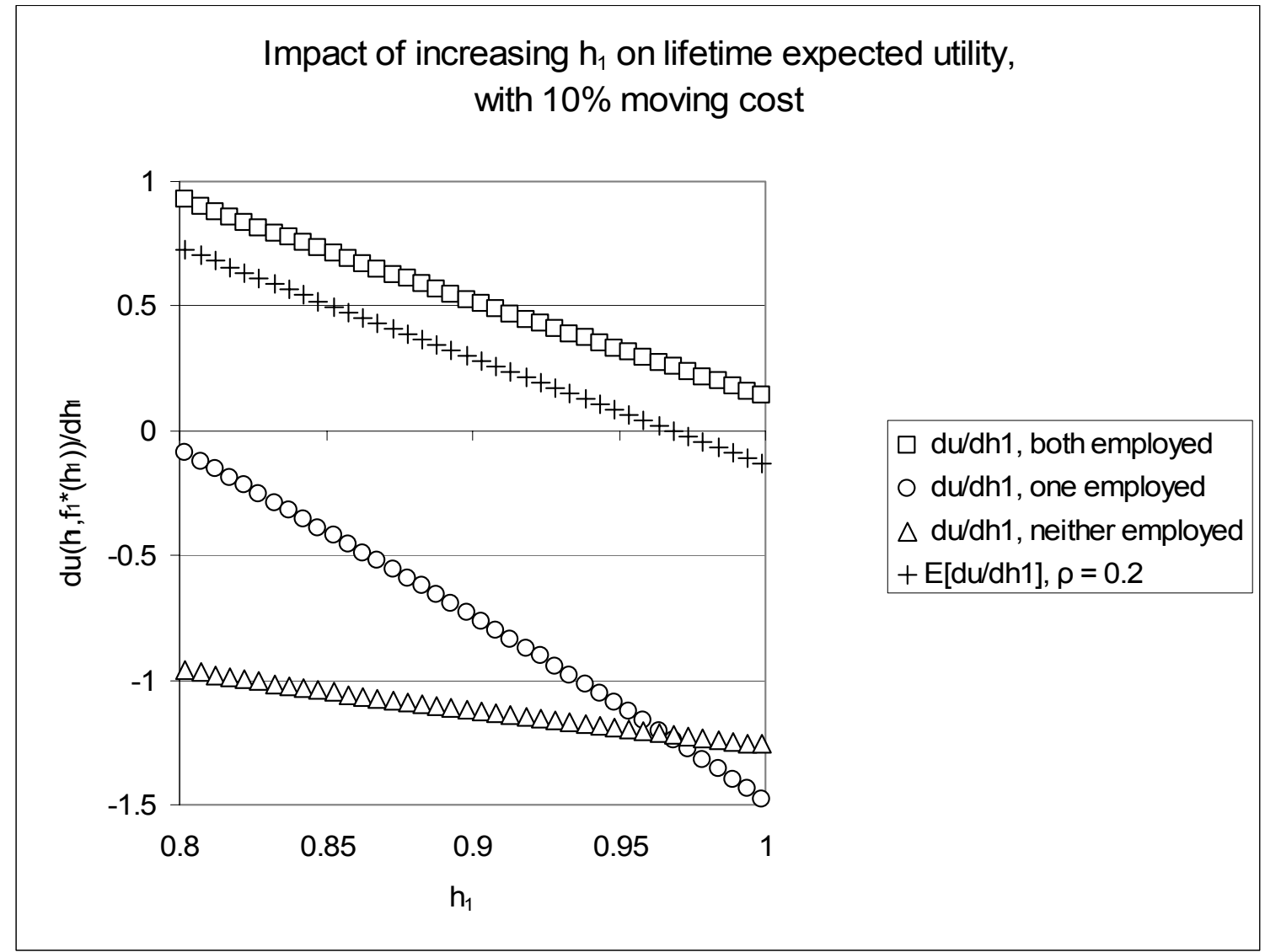

Notes: This figure plots the marginal lifetime utility of first-period housing consumption against firstperiod housing consumption, $\mathrm{h}_{1}$. The cost of adjusting housing consumption is $10 \%$ of $\mathrm{h}_{1}$. First-period income, $Y_{1}=2$; second period income for a given spouse is either $Y_{2}{ }^{E}=1$ with probability 1-p=1-q=0.9 or $\mathrm{Y}_{2}{ }^{\mathrm{U}}=0.5$ with probability $\mathrm{p}=\mathrm{q}=0.1$. The correlation of the household's unemployment shocks is $\rho=0.2$. As a result, total household second-period income is $2,1.5$, or 1 . Lifetime utility is given as the sum of log food and $\log$ housing consumption in periods 1 and 2 . Given these parameters, it is optimal to adjust housing consumption in the second period only if both spouses become unemployed within the range of values for $\mathrm{h}_{1}$ shown. 
Figure 2.4:

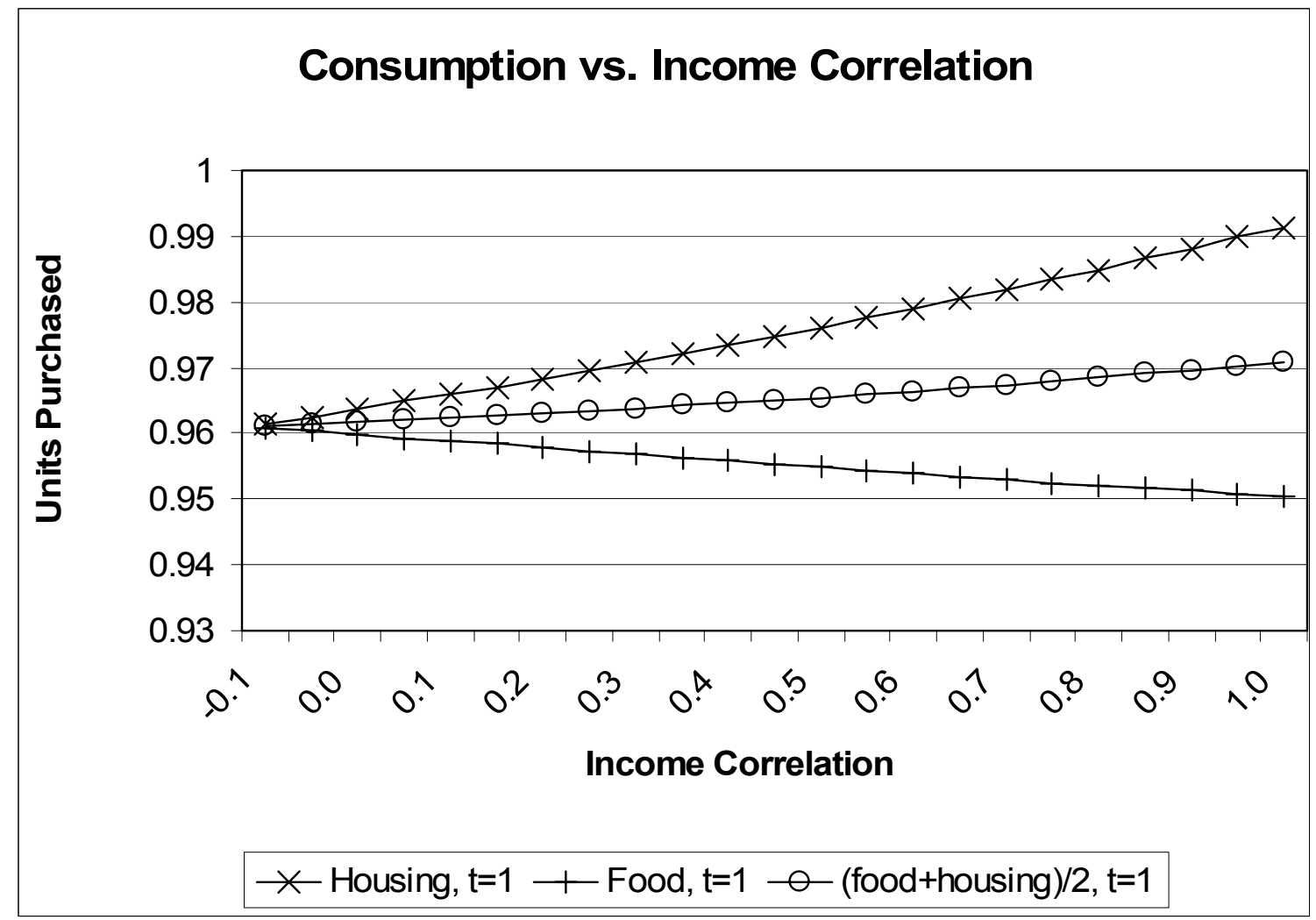

Notes: This figure plots the optimal quantity of consumption against the correlation of spouses' unemployment events, $\rho$. The cost of adjusting housing consumption is $10 \% \mathrm{of}_{1}$. First-period income, $\mathrm{Y}_{1}=2$; second period income for a given spouse is either $\mathrm{Y}_{2}{ }^{\mathrm{E}}=1$ with probability $1-\mathrm{p}=1-\mathrm{q}=0.9$ or $\mathrm{Y}_{2}{ }^{\mathrm{U}}=0.5$ with probability $\mathrm{p}=\mathrm{q}=0.1$. As a result, total household second-period income is $2,1.5$, or 1 . Lifetime utility is given as the sum of log food and log housing consumption in periods 1 and 2. Given these parameters, it is optimal to adjust housing consumption in the second period only if both spouses become unemployed. First-period housing consumption, $\mathrm{h}_{1}$, is increasing in $\rho$, while first-period food consumption, $\mathrm{f}_{1}$, is decreasing in $\rho$. Total consumption, $\mathrm{h}_{1}+\mathrm{f}_{1}$, is increasing in $\rho$. 
Figure 2.5

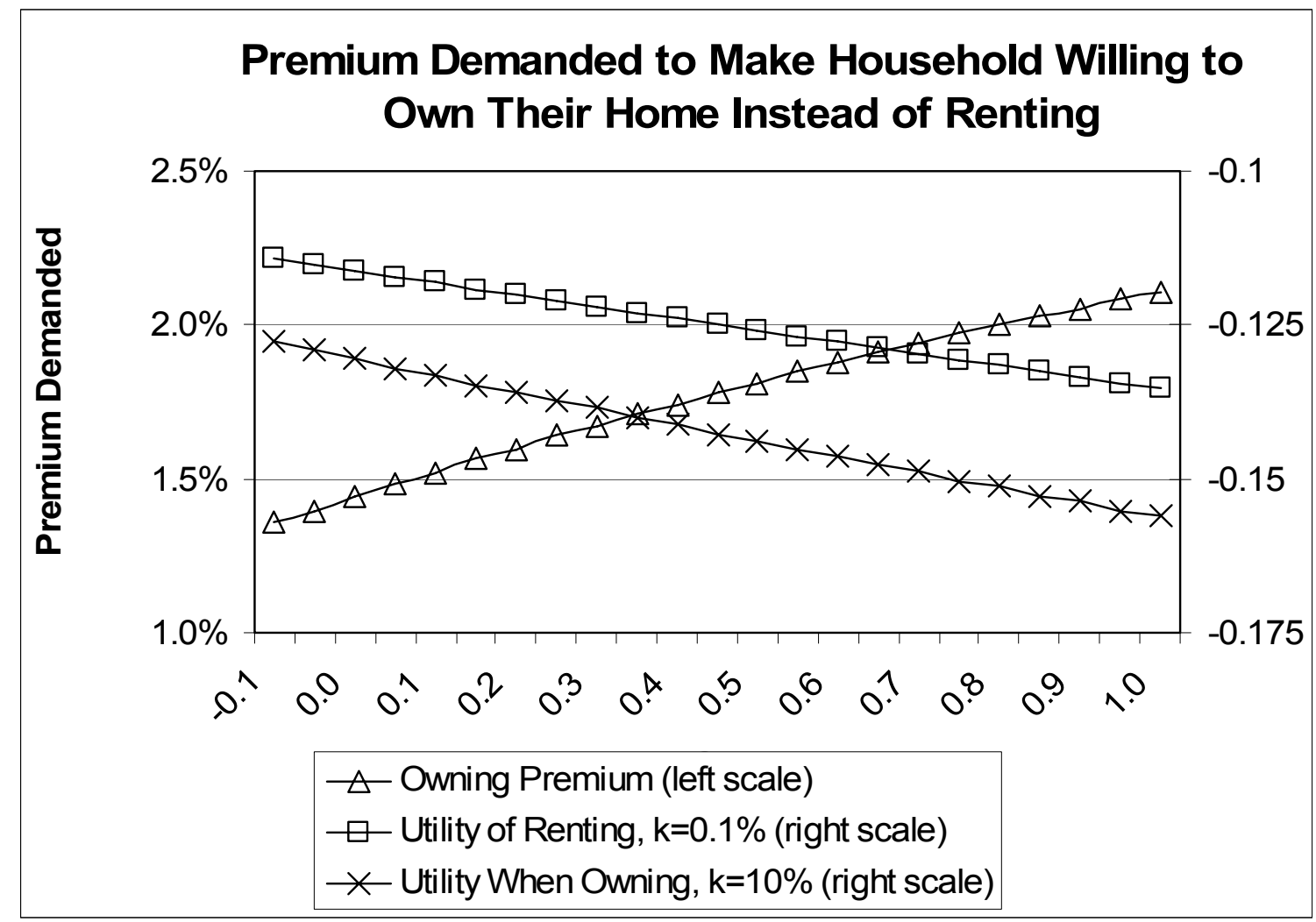

Notes: The cost of adjusting housing consumption is $10 \%$ of $\mathrm{h}_{1}$. First-period income, $\mathrm{Y}_{1}=2$; second period income for a given spouse is either $\mathrm{Y}_{2}^{\mathrm{E}}=1$ with probability $1-\mathrm{p}=1-\mathrm{q}=0.9$ or $\mathrm{Y}_{2}^{\mathrm{U}}=0.5$ with probability $\mathrm{p}=\mathrm{q}=0.1$. As a result, total household second-period income is $2,1.5$, or 1 . Lifetime utility is given as the sum of $\log$ food and $\log$ housing consumption in periods 1 and 2 . Given these parameters, it is optimal to adjust housing consumption in the second period only if both spouses become unemployed. The " $x$ " and " $\square$ " lines plot the relationship between the correlation of household labor income, $\rho$, and the utility. These lines differ in the cost of adjusting housing consumption, so that the higher moving cost corresponds to the lower utility. The higher moving cost is meant to represent as the case of a homeowner; the lower moving cost represents the case of a renter. The " $\Delta$ " line represents the demanded ownership premium, the percent by which wages in all periods and states would have to be increased to induce the agent to accept the higher moving cost over the lower moving cost. A higher premium suggests that a household is less willing to own a home and requires greater compensation for doing so. 
Table 3.1.A: IPUMS Summary statistics

\begin{tabular}{lrrrr}
\hline \multirow{2}{*}{ Variable } & \multicolumn{2}{c}{ Owners Only } & \multicolumn{2}{c}{ Renters Only } \\
\cline { 2 - 6 } & Mean & Std. Dev. & Mean & Std. Dev. \\
\hline $\begin{array}{l}\text { Husband and wife report same } \\
\text { occupation (1950 definitions) }\end{array}$ & 0.096 & 0.294 & 0.096 & 0.295 \\
$\begin{array}{l}\text { Husband and wife report same } \\
\text { industry (1950 definitions) }\end{array}$ & 0.141 & 0.348 & 0.127 & 0.333 \\
House value; monthly rent & 175,893 & 129,027 & 666 & 332 \\
Family income & 91,252 & 59,064 & 61,777 & 39,942 \\
$\begin{array}{l}\text { Husband's imputed unemployment } \\
\text { rate }(p)\end{array}$ & 0.065 & 0.022 & 0.071 & 0.025 \\
Wife's imputed unemployment rate $(q)$ & 0.135 & 0.038 & 0.147 & 0.041 \\
Husband's share of income & 0.621 & 0.170 & 0.598 & 0.181 \\
Imputed probability of moving & 0.148 & 0.083 & 0.196 & 0.093 \\
Sample average probability of moving & 0.112 & 0.315 & 0.338 & 0.473 \\
Number of observations & 231,598 & 48,464 & \\
\hline
\end{tabular}

Notes: Data are from the 1980, 1990, and 2000 IPUMS. Sample construction is detailed in Table A2.

Dollar amounts are in real (2000) dollars. The number of observations for the "same industry" row is 240,680 for owners, and 59,987 for renters. The sample size differs because a larger fraction of the IPUMS sample reports their industry than do their occupation.

Table 3.1.B: SIPP Summary statistics

\begin{tabular}{lrr}
\hline Variable & \multicolumn{1}{c}{ Mean } & Std. Dev. \\
\hline Husband and wife report same occupation & 0.032 & 0.155 \\
Husband and wife report same industry & 0.094 & 0.292 \\
Family income & 69,570 & 54,164 \\
Husband's unemployment rate & 0.086 & 0.280 \\
Wife's unemployment rate & 0.251 & 0.434
\end{tabular}

Notes: Data are from the April 1996 panel of the Survey of Income and Program Participation, which covers 48 months between April 1996 and March 2000. Sample construction is detailed in Table A2. 
Table 3.2: Top 20 Occupations by Percent of Couples Who Share the Same Occupation

\begin{tabular}{|c|c|c|c|c|}
\hline & Occupation, 1950 basis & $\begin{array}{c}\text { Same Occ. } \\
\text { Share of the } \\
\text { Occ. }\end{array}$ & $\begin{array}{l}\text { Occ. Share } \\
\text { of Sample }\end{array}$ & $\begin{array}{c}\text { Rate of } \\
\text { Same Occ. } \\
\text { With } \\
\text { Random } \\
\text { Sorting } \\
\end{array}$ \\
\hline 1 & Physicians and Surgeons & $15.05 \%$ & $0.51 \%$ & $0.25 \%$ \\
\hline 2 & Teachers & $11.91 \%$ & $5.24 \%$ & $2.16 \%$ \\
\hline 3 & Operative and Kindred Workers & $11.87 \%$ & $6.55 \%$ & $3.61 \%$ \\
\hline 4 & Managers, Officials, and Proprietors & $11.27 \%$ & $11.49 \%$ & $6.14 \%$ \\
\hline 5 & Lawyers and Judges & $10.17 \%$ & $0.81 \%$ & $0.37 \%$ \\
\hline 6 & Professors (subject matter unspecified) & $7.62 \%$ & $0.58 \%$ & $0.29 \%$ \\
\hline 7 & Managers \& Superintendents, building & $7.60 \%$ & $0.37 \%$ & $0.19 \%$ \\
\hline 8 & Professional, technical \& kindred workers & $7.28 \%$ & $3.15 \%$ & $1.63 \%$ \\
\hline 9 & Real estate agents and brokers & $6.82 \%$ & $0.83 \%$ & $0.42 \%$ \\
\hline 10 & Members of the armed services & $5.90 \%$ & $0.64 \%$ & $0.13 \%$ \\
\hline 11 & Salesmen and sales clerks & $5.52 \%$ & $4.25 \%$ & $2.10 \%$ \\
\hline 12 & Clerical and kindred workers & $4.97 \%$ & $8.68 \%$ & $3.29 \%$ \\
\hline 13 & Janitors and sextons & $4.81 \%$ & $1.46 \%$ & $0.60 \%$ \\
\hline 14 & Editors and reporters & $4.47 \%$ & $0.39 \%$ & $0.19 \%$ \\
\hline 15 & Cooks, except private household & $4.28 \%$ & $0.97 \%$ & $0.47 \%$ \\
\hline 16 & Policemen and detectives & $3.72 \%$ & $0.78 \%$ & $0.17 \%$ \\
\hline 17 & Mail carriers & $3.60 \%$ & $0.34 \%$ & $0.12 \%$ \\
\hline 18 & Insurance agents and brokers & $3.31 \%$ & $1.10 \%$ & $0.54 \%$ \\
\hline 19 & Stock and bond salesmen & $3.30 \%$ & $0.28 \%$ & $0.13 \%$ \\
\hline 20 & Service workers, except private household & $3.00 \%$ & $0.56 \%$ & $0.23 \%$ \\
\hline
\end{tabular}

Notes: Only occupations comprising at least 0.25 percent of the sample are shown in this table. Column (1) presents the ratio of the number of same occupation couples in an occupation to the number of couples where either (or both) spouse has that occupation. Column (2) is the ratio of the number of couples where either (or both) spouse has that occupation to the total number of couples. Column (3) is the fraction of couples with one or both spouses in an occupation who would share an occupation if pairings were done at random (i.e. without regard to occupation). Data are from the 1980-2000 IPUMS. 
Table 3.3: Probability of one or both spouses becoming unemployed at some point during a six-month window conditional on both initially employed, by whether the couple shares an occupation

\begin{tabular}{|c|c|c|c|c|c|c|c|}
\hline & $\begin{array}{c}\text { Probability } \\
\text { no spouses } \\
\text { unemployed } \\
\text { during } \\
\text { subsequent } \\
\text { six months }\end{array}$ & $\begin{array}{l}\text { Probability } \\
\text { at most one } \\
\text { spouse } \\
\text { unemployed } \\
\text { during } \\
\text { subsequent } \\
\text { six months } \\
\end{array}$ & $\begin{array}{l}\text { Probability } \\
\text { both spouses } \\
\text { unemployed } \\
\text { at some point } \\
\text { during } \\
\text { subsequent } \\
\text { six months }\end{array}$ & $\begin{array}{l}\text { Probability } \\
\text { husband } \\
\text { becomes } \\
\text { unemployed } \\
\text { during } \\
\text { subsequent } \\
\text { six months }\end{array}$ & $\begin{array}{c}\text { Probability } \\
\text { wife becomes } \\
\text { unemployed } \\
\text { during } \\
\text { subsequent } \\
\text { six months } \\
\end{array}$ & $\begin{array}{l}\text { Unemploy- } \\
\text { ment } \\
\text { correlation }\end{array}$ & $\begin{array}{c}\text { \# of } \\
\text { observations }\end{array}$ \\
\hline $\begin{array}{l}\text { Different } \\
\text { Occupation }\end{array}$ & 88.25 & 11.08 & 0.67 & 4.42 & 8.00 & 0.057 & 261,494 \\
\hline $\begin{array}{l}\text { Same } \\
\text { Occupation }\end{array}$ & 90.38 & 8.15 & 1.47 & 3.96 & 7.13 & 0.237 & 8,642 \\
\hline Difference & 2.13 & -2.93 & 0.80 & -0.47 & -0.87 & 0.179 & \\
\hline
\end{tabular}

Notes: The unit of observation is a couple $\times$ month. The sample consists of married couples who both report being employed in one month and who either identify as having the same or different three-digit occupation codes. The table reports the fraction of households in each category where neither, one, or both spouses report having a unemployment spell during the subsequent six months. Data are from the April 1996 panel of the Survey of Income and Program Participation. 
Table 3.4: Probability of moving over the next six months if neither, one, or both spouses become newly unemployed, for current homeowners

\begin{tabular}{lccc}
\hline & $\begin{array}{c}\text { No one } \\
\text { unemployed }\end{array}$ & $\begin{array}{c}\text { One newly } \\
\text { unemployed }\end{array}$ & $\begin{array}{c}\text { Two newly } \\
\text { unemployed }\end{array}$ \\
\cline { 2 - 4 } $\mathrm{P}$ (moving) & $2.18 \%$ & $3.96 \%$ & $9.73 \%$ \\
Marginal P(moving) & & $1.78 \%$ & $5.77 \%$ \\
Number of observations & 219,968 & 4,119 & 113 \\
\hline
\end{tabular}

Notes: The unit of observation is a couple $\times$ month. The sample consists of married couples who both report being employed in one month and then report themselves as neither unemployed, one unemployed, or both unemployed in the next month. The table reports the fraction of households in each category who move to a new home, and the number of people in each category. The probability of moving measures whether there will be at least one change of address during subsequent six months. Data are from the April 1996 panel of the Survey of Income and Program Participation. 
Table 3.5: The effect of higher correlation in unemployment risk on log house value, for homeowners

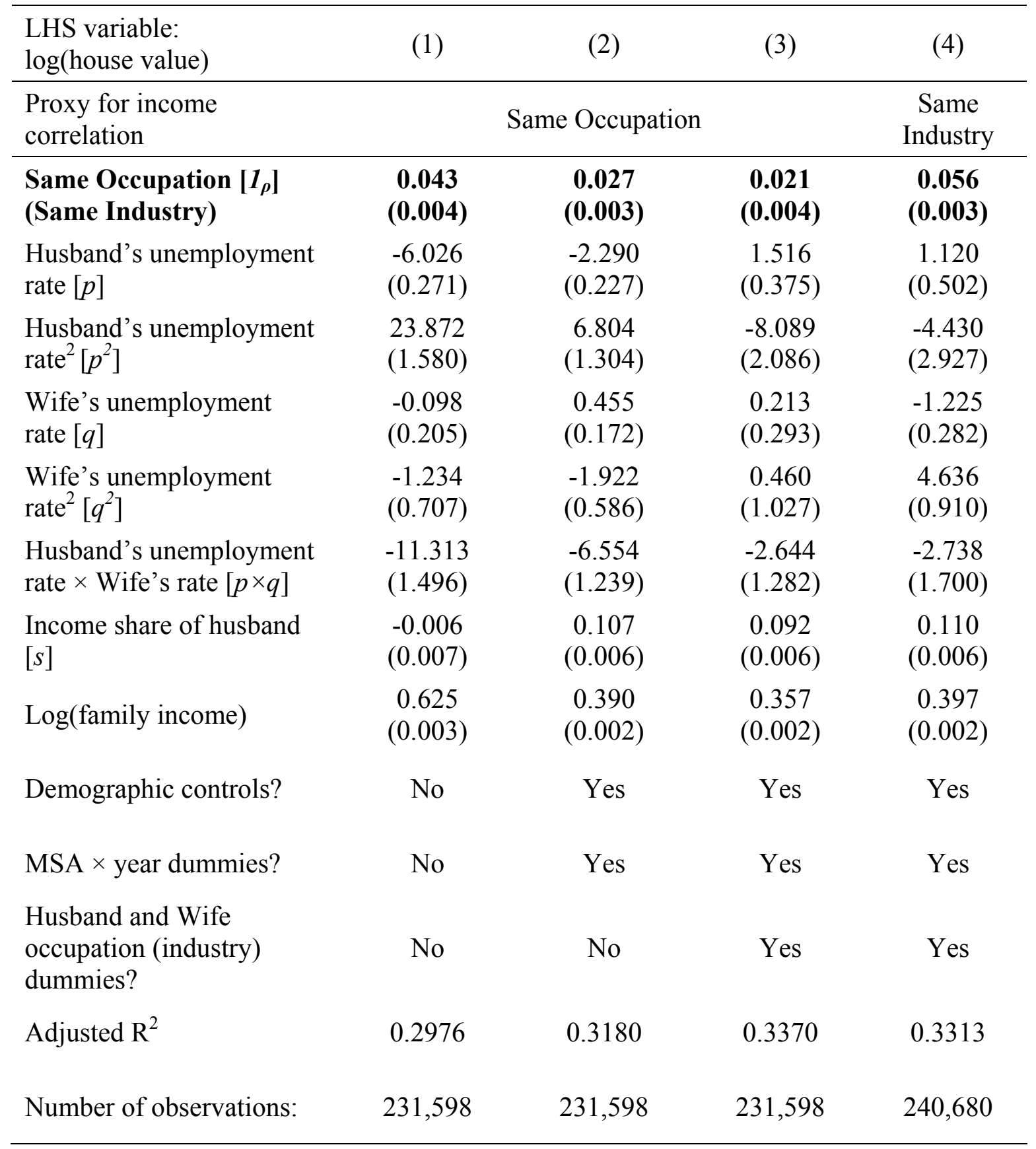

Notes: Left-hand-side variable is $\log$ (house value). All specifications include year dummies. Sample consists of married homeowner households where both spouses work full-time. More details are in Table A2. Demographic controls in columns (2) - (4) include dummies for: the number of persons in the household, the number of kids in the household, the educations of the husband and wife, and age brackets for the head and spouse. Data are from the 1980-2000 IPUMS. 
Table 3.6: The effect of same occupation on log house value, estimated separately for various sample splits, for homeowners

\section{Splits by:}

Decade:

Same occupation

$\mathrm{N}$

Husband's Age
Same occupation
N

Education

Same occupation

$\mathrm{N}$

\section{Family Income}

Same occupation

$\mathrm{N}$

Husband's income share

Same occupation

$\begin{array}{ccc}\underline{1980} & \underline{1990} & \underline{2000} \\ 0.017 & 0.023 & 0.017 \\ (0.007) & (0.006) & (0.007) \\ 61,085 & 94,879 & 75,634\end{array}$

$\leqq 45$

0.022

$(0.005)$

124,351 $\underline{46-64}$

0.017

(0.006)

102,847 $\underline{\text { Some college for } \geq 1 \text { spouse }}$

0.016

(0.004)

166,915

$\underline{\text { Above median }}$

0.005

(0.004)

130,018

Between 0.4 and 0.8

0.024

(0.004)
No college for either spouse

0.034

(0.009)

64,683

Below median

0.033

(0.007)

101,580

\section{$\mathrm{N}$}

177,629

$\underline{\text { Not between } 0.4 \text { and } 0.8}$

0.017

(0.009)

\section{3,969}

Notes: This table reports the estimated coefficient and standard error on the "Same Occupation" dummy variable from a regression of log house value on the "same occupation" dummy, plus controls. The regression is run separately (e.g.: all variables are fully interacted) for each of the samples in the splits. The samples are drawn from the 1980-2000 IPUMS. These regressions use the same specification as in column 3 of table 3.5, including unemployment risk controls, husband's income share, log family income, demographic dummies, occupation dummies for both husband and wife, and MSA $\times$ year dummies (MSA dummies alone in the single-decade regressions). Median income is calculated by year. The medians are (in real \$2000): $1980-68,325 ; 1990-72,831 ; 2000-80,000$. "Some college" means at least one of the two spouses have had at least one year of post-high school education. The "income share" cutoffs of 0.4 and 0.8 are approximately one standard deviation above and below the mean of 0.61 . The number of observations in each row adds up to 231,598, except for the "Husband's Age" specification, which excludes the " $65+$ " category (4,400 observations). 
Table 3.7: The effect of same occupation on the demand for housing and homeownership, and the impact of effective moving costs

\begin{tabular}{|c|c|c|c|c|c|c|}
\hline & $(1)$ & $(2)$ & (3) & (4) & $(5)$ & (6) \\
\hline LHS variable: & \multicolumn{2}{|c|}{ Log(House Value) } & \multicolumn{2}{|c|}{$\log ($ Rent $)$} & \multicolumn{2}{|c|}{ Own $=1$} \\
\hline Sample: & \multicolumn{2}{|c|}{ Homeowners } & \multicolumn{2}{|c|}{ Renters } & \multicolumn{2}{|c|}{ Renters and Homeowners } \\
\hline Same Occupation & $\begin{array}{c}0.021 \\
(0.004)\end{array}$ & $\begin{array}{c}0.034 \\
(0.007)\end{array}$ & $\begin{array}{l}-0.002 \\
(0.017)\end{array}$ & $\begin{array}{l}-0.050 \\
(0.034)\end{array}$ & $\begin{array}{l}-0.014 \\
(0.003)\end{array}$ & $\begin{array}{l}-0.027 \\
(0.005)\end{array}$ \\
\hline Imputed $\mathrm{P}$ (moving) & & $\begin{array}{l}-0.933 \\
(0.069)\end{array}$ & & $\begin{array}{l}0.718 \\
(0.265)\end{array}$ & & $\begin{array}{l}-0.624 \\
(0.045)\end{array}$ \\
\hline $\begin{array}{l}\text { Same occupation } \times \text { Imputed } \\
\mathbf{P}(\text { moving })\end{array}$ & & $\begin{array}{l}-0.088 \\
(0.039)\end{array}$ & & $\begin{array}{c}0.248 \\
(0.156)\end{array}$ & & $\begin{array}{c}0.084 \\
(0.026)\end{array}$ \\
\hline Log(family income) & $\begin{array}{c}0.357 \\
(0.002)\end{array}$ & $\begin{array}{c}0.358 \\
(0.002)\end{array}$ & $\begin{array}{c}0.201 \\
(0.009)\end{array}$ & $\begin{array}{c}0.200 \\
(0.009)\end{array}$ & $\begin{array}{c}0.177 \\
(0.002)\end{array}$ & $\begin{array}{c}0.178 \\
(0.002)\end{array}$ \\
\hline Demographic controls? & Yes & Yes & Yes & Yes & Yes & Yes \\
\hline MSA $\times$ year dummies? & Yes & Yes & Yes & Yes & Yes & Yes \\
\hline Occ. dummies for each spouse & Yes & Yes & Yes & Yes & Yes & Yes \\
\hline Adjusted $\mathrm{R}^{2}$ & 0.3370 & 0.3366 & 0.1310 & 0.1312 & 0.1414 & 0.1423 \\
\hline Number of Observations & 231,598 & 231,598 & 58,464 & 58,464 & 290,062 & 290,062 \\
\hline
\end{tabular}

Notes: Sample is the 1980-2000 IPUMS. These regressions use the same set of controls as in column 3 of table 3.5, including unemployment risk controls, husband's income share, log family income, demographic dummies, occupation dummies for both husband and wife, and MSA $\times$ year dummies. The probability of moving, in even numbered columns, is imputed as the fraction of households in an age $\times$ marital status $\times$ presence of kids cell (excluding the household that the moving rate is being imputed to) that moved over the prior year. The reported coefficients for owners in columns (1) and (2) and their analogs for renters in (3) and (4) are statistically significantly different from each other. Columns (5) and (6) report the results from a linear probability model. 
Table 3.8: The effect of unemployment insurance on the relationship between same occupation and house value, for homeowners

\begin{tabular}{lccc}
\hline $\begin{array}{l}\text { LHS variable: } \\
\log (\text { house value) }\end{array}$ & $(1)$ & $(2)$ & $(3)$ \\
\hline $\begin{array}{l}\text { Functional form of } \\
\text { UI replacement rate }(\mathrm{RR})\end{array}$ & $\begin{array}{c}\text { Dummy for } \\
\text { bottom decile }\end{array}$ & $\begin{array}{c}\text { Dummy for } \\
\text { bottom } \\
\text { quartile }\end{array}$ & Linear \\
\hline Same Occupation $\times$ Husband's income share $\times$ & 0.077 & 0.076 & 0.203 \\
Wife's share $\left[1_{\rho} \times S \times(1-s)\right]$ & $(0.019)$ & $(0.020)$ & $(0.065)$ \\
Same Occupation $\times$ Husband's income share $\times$ & 0.267 & 0.148 & -0.323 \\
Wife's share $\times$ RR & $(0.079)$ & $(0.056)$ & $(0.190)$ \\
Adjusted R & 0.5539 & 0.5550 & 0.5568 \\
Occupation dummies? & No & No & No \\
Same Occupation $\times$ Husband's income share $\times$ & 0.049 & 0.057 & 0.036 \\
Wife's share $\left[1_{\rho} \times S \times(1-S)\right]$ & $(0.022)$ & $(0.023)$ & $(0.063)$ \\
Same Occupation $\times$ Husband's income share $\times$ & 0.084 & 0.027 & 0.056 \\
Wife's share $\times$ RR & $(0.072)$ & $(0.050)$ & $(0.190)$ \\
Adjusted R ${ }^{2}$ & 0.5662 & 0.5670 & 0.5682 \\
Occupation dummies? & Yes & Yes & Yes \\
\hline
\end{tabular}

Notes: Robust standard errors, corrected for correlation by state x year x segment on the UI schedule, are in parentheses. Across the columns, UI segments are bottom decile/top 90 percent; bottom quartile/top 75 percent; and in the linear specification, the segments are the linear portions of the UI replacement schedule. Each spouse can be on one of three sections: the spouse is ineligible, the spouse's income is below or at the state benefits maximum; or the spouse's income is above the benefits maximum. Collectively, there are six possible combinations and five are populated with households in our data. The empty segment is both spouses having incomes above the benefits maximum. In addition to the variables reported above, all columns include controls for log family income, $s, s \times(1-$ $s), p \times s, q \times(1-s), p^{2} \times s, q^{2} \times(1-s)$, (where $s$ is the husband's share of household wage income and $p$ and $q$ are the husband's and wife's imputed unemployment rates, respectively) as well as each of the preceding variables interacted with the replacement rate measure. Each column also includes MSA $\times$ year dummies, state $\times$ year dummies, and controls for the number of persons in the household, number of children, educational attainment of the husband and wife, and age of the husband and wife. The bottom panel also includes occupation dummies for the husband and wife. Data are from the 1990 and 2000 IPUMS, with the UI replacement rate imputed based off of state of residence, year, and income of the husband and wife. RR is the income-weighted average of the husband's and wife's individual UI replacement rates. The sample average husband's share of income is 0.62 . The number of observations is 156,285 . 
Appendix Table A.1: Model Calibration for Various Parameters

\begin{tabular}{|c|c|c|c|c|c|c|c|c|c|c|c|c|c|c|c|c|}
\hline 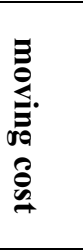 & تِّ & 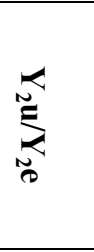 & $\Xi_{*}$ & $\vec{*}$ & 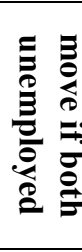 & 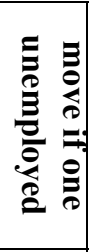 & 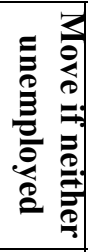 & $\begin{array}{l}\stackrel{\varrho}{\varrho} \\
\vdots \\
\equiv\end{array}$ & $\frac{\varrho}{\equiv}$ & 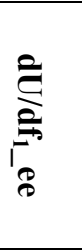 & $\frac{\varrho}{\equiv}$ & 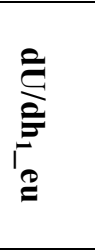 & 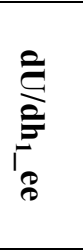 & $\frac{\hat{\sigma}}{\hat{\sigma}}$ & $\frac{\varrho}{\Rightarrow}$ & 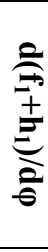 \\
\hline $.1 \%$ & $10 \%$ & $50 \%$ & 0.964 & 0.965 & Yes & Yes & Yes & -0.83 & -0.24 & 0.07 & -0.83 & -0.24 & 0.07 & - & - & - \\
\hline $1 \%$ & $10 \%$ & $50 \%$ & 0.997 & 0.964 & Yes & Yes & No & -0.91 & -0.27 & 0.08 & -0.96 & -0.32 & 0.09 & + & - & - \\
\hline $5 \%$ & $10 \%$ & $50 \%$ & 0.994 & 0.963 & Yes & Yes & No & -0.98 & -0.30 & 0.09 & -1.11 & -0.40 & 0.11 & + & - & - \\
\hline $10 \%$ & $10 \%$ & $50 \%$ & 0.968 & 0.958 & Yes & No & No & -1.00 & -0.61 & 0.14 & -1.22 & -1.24 & 0.26 & + & - & + \\
\hline $20 \%$ & $10 \%$ & $50 \%$ & 0.967 & 0.957 & Yes & No & No & -1.22 & -0.59 & 0.14 & -1.68 & -1.21 & 0.27 & + & - & + \\
\hline $50 \%$ & $10 \%$ & $50 \%$ & 0.939 & 0.939 & No & No & No & -4.42 & -0.40 & 0.22 & -8.83 & -0.80 & 0.44 & - & - & - \\
\hline $10 \%$ & $.01 \%$ & $50 \%$ & 1.000 & 1.000 & Yes & No & No & -1.22 & -1.00 & 0.00 & -1.44 & -2.00 & 0.00 & + & - & + \\
\hline $10 \%$ & $5 \%$ & $50 \%$ & 0.982 & 0.977 & Yes & No & No & -1.10 & -0.77 & 0.08 & -1.32 & -1.55 & 0.15 & + & - & + \\
\hline $10 \%$ & $10 \%$ & $50 \%$ & 0.968 & 0.958 & Yes & No & No & -1.00 & -0.61 & 0.14 & -1.22 & -1.24 & 0.26 & + & - & + \\
\hline $10 \%$ & $15 \%$ & $50 \%$ & 0.957 & 0.940 & Yes & No & No & -0.92 & -0.48 & 0.19 & -1.14 & -1.00 & 0.35 & + & - & + \\
\hline $10 \%$ & $20 \%$ & $50 \%$ & 0.946 & 0.925 & Yes & No & No & -0.85 & -0.38 & 0.24 & -1.07 & -0.81 & 0.42 & + & - & + \\
\hline $10 \%$ & $30 \%$ & $50 \%$ & 0.927 & 0.895 & Yes & No & No & -0.73 & -0.22 & 0.32 & -0.95 & -0.51 & 0.56 & + & - & + \\
\hline $10 \%$ & $10 \%$ & $20 \%$ & 0.979 & 0.908 & Yes & Yes & No & -3.71 & -0.54 & 0.22 & -4.27 & -0.79 & 0.28 & - & - & - \\
\hline $10 \%$ & $10 \%$ & $30 \%$ & 0.984 & 0.932 & Yes & Yes & No & -2.34 & -0.48 & 0.16 & -2.74 & -0.70 & 0.21 & - & - & - \\
\hline $10 \%$ & $10 \%$ & $40 \%$ & 0.958 & 0.943 & Yes & No & No & -1.43 & -0.79 & 0.18 & -1.69 & -1.60 & 0.34 & + & - & + \\
\hline $10 \%$ & $10 \%$ & $50 \%$ & 0.968 & 0.958 & Yes & No & No & -1.00 & -0.61 & 0.14 & -1.22 & -1.24 & 0.26 & + & - & + \\
\hline $10 \%$ & $10 \%$ & $60 \%$ & 0.977 & 0.970 & Yes & No & No & -0.70 & -0.45 & 0.10 & -0.88 & -0.91 & 0.19 & + & - & + \\
\hline $10 \%$ & $10 \%$ & $70 \%$ & 0.977 & 0.977 & No & No & No & -1.12 & -0.28 & 0.09 & -2.23 & -0.56 & 0.17 & - & - & - \\
\hline
\end{tabular}

Notes: This table presents a summary of calibration results for various parameter values. All rows assume $\mathrm{Y}_{1}=2, \mathrm{Y}_{2}^{\mathrm{E}}=1$. Lifetime utility is given as the sum of $\log$ food and $\log$ housing consumption in periods 1 and 2 . The first three rows show $k, p$ and $q$, and $\mathrm{Y}_{2}^{\mathrm{U}}$, respectively. Given these parameter values, the optimal levels of initial housing and food consumption are given in the fourth and fifth rows. The sixth, seventh, and eighth rows show under what circumstances it will be optimal to move. The ninth through fourteenth rows show the impact of changes in initial food or housing consumption on utility in various states of the world. The final three columns show how increasing the correlation of unemployment (introducing a mean-preserving spread in risk) impacts consumption. A "+" indicates increased consumption in the face of increased risk. A "-" in the final column indicates an aggregate precautionary saving motive. 
Appendix Table A.2: Sample Construction

\begin{tabular}{lrr}
\hline Restriction & Number lost & Total remaining \\
\hline Data source: IPUMS & & \\
Original sample & & $2,778,194$ \\
Live in an MSA & $1,016,455$ & $1,761,767$ \\
Married & 779,536 & 982,231 \\
Husband and wife both age 25 or over & 63,992 & 918,239 \\
Listed occupations & 20,499 & 897,740 \\
Husband and wife both work full-time & 572,470 & 325,270 \\
8 or fewer people in household & 1,513 & 323,757 \\
Not a farm household & 2,318 & 321,439 \\
Family income above zero and not missing & 113 & 321,326 \\
Both husband and wife have income $\geq 0$ & 1,160 & 320,166 \\
Occupation not rare (contains $>$ 200 persons/year) & 17,806 & 302,360 \\
Cell size for imputing probability of moving $\geq 30$ & 185 & 302,175 \\
House value or rent non-missing and $>0$ & 12,113 & 290,062 \\
& & \\
Data source: SIPP & & \\
Original sample (person $\times$ month) & 130,433 & 270,136 \\
Married couple households $\times$ month & & $3,897,211$ \\
Drop extended families & & 779,459 \\
Reported occupation & $3,117,752$ & 618,684 \\
Can follow employment status for six months & 127,711 & 490,973 \\
Employed in current month & 90,404 & 400,569 \\
\hline
\end{tabular}

Sources: 1980, 1990, and 2000 IPUMS; April 1996 panel of the SIPP 